GEORGE L. PERRY

Brookings Institution

CHARLES L. SCHULTZE

Brookings Institution

\title{
Was This Recession Different? Are They All Different?
}

THE RECENT RECESSION and disappointing recovery have renewed interest in the cyclical behavior of the economy. The latest recession was the eighth in the last forty years. Each has involved massive job losses and sharply reduced rates of capital formation. Each has also reduced the inflation rate, although not always for long. The leading candidates for explaining these episodes are variations in fiscal and monetary policies, shocks to the economy from exogenous developments apart from policy, the internal dynamics of the economy, and combinations of some or all of these factors.

In this paper we attempt to answer a number of questions about the recent recession and its predecessors. Are recessions generically special in the sense that economic relations are different in some systematic way? If they are different from nonrecession periods, what are the family resemblances among recessions and in what ways have they differed from each other? In particular, how was the latest recession different from others, either in how economic activity unfolded and reacted to policy, in how policy changed in reaction to economic developments, in what brought on the recession, or in what made the initial stages of recovery so weak? Have financial developments played a special role in the latest recession and the weak recovery from it? How potent are fiscal and monetary policies around recessions, how much of the variations in output do they explain, and how much is left to be explained by shocks?

The paper has three main parts. First, we undertake a comparative analysis of the behavior and interaction of the main components of out- 
put and major policy variables around recessions. Second, we look at some unusual developments, particularly in employment, that may help explain some of the recent weakness in the recovery. Third, we examine whether financial developments--in particular, bank capital shortages and business balance sheet problems_played a special role in inducing the latest recession or hindering its recovery.

\section{A Comparative Analysis of Recession and Recovery}

We first summarize the actual behavior of output and policy variables in the six recessions and then turn to how much of this behavior is a surprise, not readily explained by relatively simple econometric relations among the variables. Our analysis is based primarily on the last six U.S. recessions, counting the $1980-82$ period as one recession, as we do throughout the paper, although the National Bureau of Economic Research (NBER) count breaks it into two. We did not go back in time before the mid-1950s because the two previous recessions took place in the aftermath of wars and with the economy awash in liquidity, so their relevance for today appeared limited.

\section{The Broad Aggregates}

Table 1 shows changes in gross domestic product, final sales, and inventory accumulation relative to the trend in potential GDP, expressed as a percent of potential GDP. The changes are shown for the period before, during, and after the six recessions. We use these three subperiods throughout the paper, showing performance during recoveries both after five quarters, when the latest recovery was exceptionally weak, and after seven quarters, which is the latest period for which we have data on the most recent recovery. ${ }^{1}$ The standard deviations shown in the table for each subperiod refer to the dispersion of performance for the subperiod across the six recessions. We organize our main analysis

1. For our measure of potential (high employment or trend) GDP, we used unpublished quarterly estimates as calculated by the Congressional Budget Office (CBO). Although we would estimate potential output somewhat differently (in particular, we would place the level of potential higher than the CBO series in the earlier years under review), we are satisfied that this series captures the trend growth in GDP around periods of recession. 
Table 1. Gross Domestic Product, Final Sales, and Inventory Investment around Recessions

Change as percent of potential GDP

\begin{tabular}{|c|c|c|c|c|c|c|}
\hline \multirow[b]{2}{*}{ Category } & \multirow[b]{2}{*}{ Recession } & \multicolumn{5}{|c|}{ Interval } \\
\hline & & $\begin{array}{c}(P-4) \\
\text { to } P\end{array}$ & $P$ to $T$ & $\begin{array}{c}T \text { to } \\
(T+5)\end{array}$ & $\begin{array}{c}T \text { to } \\
(T+7)\end{array}$ & $\begin{array}{l}P \text { to } T \\
\text { (a.r.) }\end{array}$ \\
\hline \multirow{10}{*}{$\begin{array}{l}\text { Gross domestic } \\
\text { product }\end{array}$} & $1957: 3-1958: 2$ & -0.7 & -5.8 & 3.9 & 4.2 & -7.7 \\
\hline & 1960:2-1961:1 & -1.9 & -2.0 & 2.7 & 1.6 & -2.7 \\
\hline & $1969: 4-1970: 4$ & -1.8 & -3.8 & 1.5 & 3.1 & -3.8 \\
\hline & 1973:4-1975:1 & 0.1 & -8.8 & 2.7 & 3.0 & -7.0 \\
\hline & $1980: 1-1982: 4$ & -2.0 & -7.9 & 5.3 & 6.1 & -2.9 \\
\hline & 1990:3-1991:1 & -1.2 & -2.9 & -0.6 & 0.6 & -5.9 \\
\hline & Mean (excluding 1990-91) & -1.3 & -5.7 & 3.2 & 3.6 & -4.8 \\
\hline & Mean & -1.3 & -5.2 & 2.6 & 3.1 & -5.0 \\
\hline & Standard deviation & 0.7 & 2.5 & 1.8 & 1.8 & 2.0 \\
\hline & 1990-91, less mean others & 0.0 & 2.7 & -3.8 & -3.0 & -1.0 \\
\hline \multirow[t]{10}{*}{ Final sales } & $1957: 3-1958: 2$ & -0.6 & -4.6 & 3.3 & 2.1 & -6.2 \\
\hline & 1960:2-1961:1 & -1.0 & -1.3 & 1.6 & 0.8 & -1.7 \\
\hline & $1969: 4-1970: 4$ & -2.1 & -3.0 & 0.8 & 1.9 & -3.0 \\
\hline & 1973:4-1975:1 & -1.2 & -6.0 & 1.0 & 1.8 & -4.8 \\
\hline & $1980: 1-1982: 4$ & -1.6 & -6.5 & 2.5 & 3.4 & -2.4 \\
\hline & 1990:3-1991:1 & -1.1 & -2.2 & -1.2 & -0.1 & -4.4 \\
\hline & Mean (excluding 1990-91) & -1.3 & -4.3 & 1.8 & 2.0 & -3.6 \\
\hline & Mean & -1.2 & -3.9 & 1.3 & 1.6 & -3.7 \\
\hline & Standard deviation & 0.5 & 1.9 & 1.4 & 1.1 & 1.5 \\
\hline & 1990-91, less mean others & 0.1 & 2.1 & -3.1 & -2.1 & -0.8 \\
\hline \multirow{10}{*}{$\begin{array}{l}\text { Inventory } \\
\text { investment }\end{array}$} & 1957:3-1958:2 & -0.2 & -1.1 & 0.6 & 2.0 & -1.5 \\
\hline & 1960:2-1961:1 & -0.9 & -0.8 & 1.1 & 0.7 & -1.0 \\
\hline & 1969:4-1970:4 & 0.2 & -0.8 & 0.7 & 1.2 & -0.8 \\
\hline & $1973: 4-1975: 1$ & 1.3 & -2.8 & 1.8 & 1.2 & -2.2 \\
\hline & 1980:1-1982:4 & -0.4 & -1.4 & 2.8 & 2.7 & -0.5 \\
\hline & 1990:3-1991:1 & -0.1 & -0.7 & 0.7 & 0.7 & -1.5 \\
\hline & Mean (excluding 1990-91) & 0.0 & -1.4 & 1.4 & 1.6 & -1.2 \\
\hline & Mean & 0.0 & -1.3 & 1.3 & 1.4 & -1.3 \\
\hline & Standard deviation & 0.7 & 0.7 & 0.8 & 0.7 & 0.6 \\
\hline & 1990-91, less mean others & -0.1 & 0.6 & -0.7 & -0.9 & -0.3 \\
\hline
\end{tabular}

Source: Authors' calculations based on the National Income and Product Accounts (NIPA) and unpublished Congressional Budget Office (CBO) estimates.

using these subperiods because we suspect it is useful to view recessions as episodes in which economic relations are somewhat changed from other periods, a suspicion that is supported by regressions reported below. We use the official dating of recessions because it is broadly accepted.

During the average recession, GDP fell by 5.2 percent relative to trend, or by an annual rate of 5.0 percent. GDP is more cyclical than final 
sales, reflecting the procyclical behavior of inventories over these intervals. Only in the period directly preceding the recession of 1973 did inventories play a significant, although temporary, role in buffering GDP against a final sales decline. In the current recovery, however, a rise in inventory accumulation has caused GDP to rise relative to trend at a time when final sales were still losing ground. The standard deviation of GDP is substantially higher than that of final sales before, during, and after recessions. At 1.8 percent of GDP, the standard deviation for the first seven quarters of recoveries is high enough to discredit the idea that all recoveries-even before the latest one-look alike.

The most striking regularity revealed in table 1 is the weakness of final sales in the four quarters preceding cyclical peaks, with a mean decline relative to trend of 1.3 percent and a standard deviation of only 0.5 . The latest recession is very near the average. This weakness in final sales over the four quarters leading up to recession comes close to being a feature of the economy that predicts recessions. Figure 1 examines final sales relative to trend over all four-quarter intervals. Only from late 1966 to early 1967 did the four-quarter sum turn clearly negative without presaging a recession. At that time, the investment tax credit had been suspended in the fall of 1966 to cool off the economy, only to be reinstituted the following winter in response to worries that the economy was weakening too much.

There is considerably more dispersion across recessions from peak to trough and even during the quarters of recovery. However, the current recovery is the only one in which the increase in final sales did not keep up with trend, even after seven quarters. In the five previous recoveries, final sales rose relative to trend by an average of 2.0 percent. Measured after five quarters, the current recovery was 3.1 percent behind the average of the five previous recoveries.

During the average recovery, final sales account for only 52 percent of the rise in GDP relative to trend (compared with more than 99 percent over all recession and nonrecession periods); the percent is similar for all recoveries except the last one. This regularity exists alongside the considerable variation in the growth of both GDP and final sales during recoveries. The contribution of inventory investment to recoveries is not only large, but has a quite low standard error and, in a cross-section across recoveries, a remarkable correlation of 0.91 with final sales over the first seven quarters. During recessions this correlation is 0.72 and 
Figure 1. Percentage Change in Final Sales Relative to Potential GDP, Four-Quarter Moving Sum ${ }^{\mathrm{a}}$

Percentage change

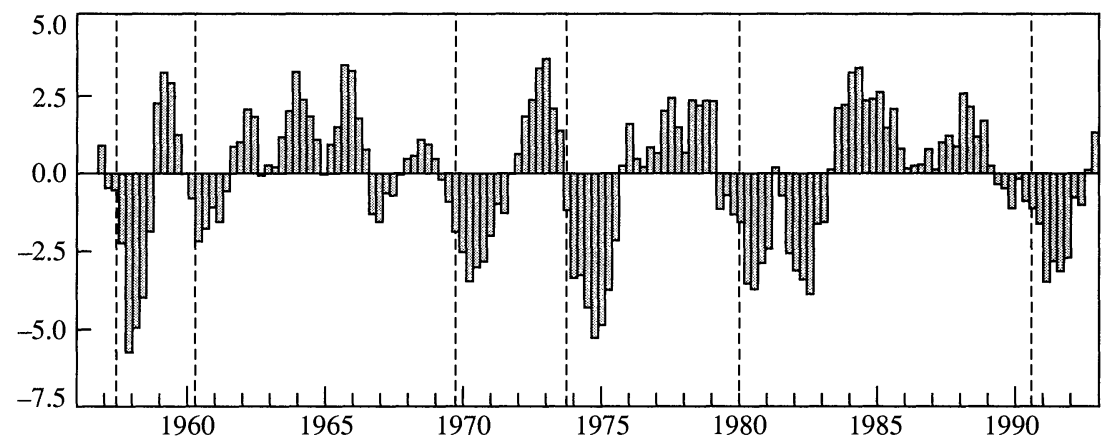

Source: Authors' calculations based on National Income and Product Accounts (NIPA) and unpublished Congressional Budget Office (CBO) estimates.

a. Vertical lines are NBER-dated business cycle peak quarters.

during the four quarters preceding peaks it is -0.17 , suggesting that there may have been unintended accumulation of stocks before some cyclical peaks.

We draw several inferences from these patterns. Recessions are systematically preceded by weakness in the growth of final sales, but not by the contribution of inventory investment to production. Even if unintended accumulation of stocks has occurred before peaks, recessions must typically originate elsewhere, with inventory buildups slightly altering the timing of peaks. Weakening final sales leading up to recession could reflect exogenous shocks or may be the intended or unintended result of policy changes. They may also reflect some endogenous dynamics of the economy that are not offset by policy adjustments.

After peaks, the endogenous dynamics of the economy seem to be more important. The correlation between final sales in the year before recessions and final sales during recessions is less than 0.1 . The correlation between the depth of the recession and strength of the recovery is -0.48 after five quarters and -0.81 after seven quarters. These negative correlations would be consistent with some accelerator models describing the dynamics of the economy, but would not be predicted if the economy's motion were characterized by a random walk with drift. The very high correlation between the contribution of final sales and inventory investment in recoveries suggests that inventories are responding 
in a systematic way to final sales during this period. Inventory imbalances are corrected quickly, but adjusting output to correct them adds substantially to the size of the downturn and, even more, to the strength of the recovery.

\section{Components of Final Sales}

Table 2 provides a more disaggregated view by examining the major components of final sales around recessions. For each component, the table shows its change relative to trend, as a percent of potential GDP. Thus, except for rounding, the changes add to the changes in final sales relative to trend shown in table 1 , and the change shown for each component shows its contribution to the percent change in GDP relative to trend during the period. ${ }^{2}$ We should emphasize that, because the entries are scaled to show their contribution to potential GDP, table 2 provides little sense of the actual volatility of demand in some of these sectors. For example, expressed as a percent of themselves rather than of potential GDP, the changes in nonresidential construction would be thirty-five times as large, the changes in residential construction would be twentyfive times as large, and the changes in consumer durables would be eleven times as large as the entries in the table. Where it simplifies the following discussions, consumption (or other components) measured relative to trend will be referred to as relative consumption (or relative other components).

consumption. As Christopher D. Carroll and Robert E. Hall have recently observed, the variation in consumption around recessions is considerably greater than a simple permanent income model would predict. ${ }^{3}$ Relative consumption declined before each recession and, on average, accounted for 58 percent of the decline in relative final sales. It declined in every recession, accounting for 49 percent of the decline in final sales, and rose in every recovery, more than accounting for the rise in final sales. After seven quarters, consumption on average had almost made up for its decline relative to trend in the recession, but not for the

2. Letting $X$ be a component, $Q$ be GDP, and an asterisk designate the potential levels of a variable, the entries in table 2 are calculated as $\Delta \ln \left(X / Q^{*}\right) X / Q^{*}$. Assuming the potential growth in each component equals the potential growth in GDP, this expression equals $\left(\Delta \ln X-\Delta \ln X^{*}\right) X / Q^{*}$, which is approximately $\left(\Delta X-\Delta X^{*}\right) / Q^{*}$.

3. Carroll (1992) and Hall (1993). 
decline in the year preceding the recession. Shocks to consumption may have contributed to causing recessions. But the systematically procyclical behavior of relative consumption over all three subperiods in all recessions suggests its behavior is mainly endogenous to the recession experience. Consumption responds promptly to the ups and downs of the overall economy, driven by short-run variations in income, confidence, interest rates, or some other developments characteristic of recessionary episodes.

RESIDENTIAL CONSTRUCTION. Although the lead of residential construction downturns relative to business cycle peaks has long been recognized, we were still surprised by the regularity of this behavior shown in table 2 . On average, this small sector accounts for 58 percent of the shortfall of final sales relative to trend in the year preceding recessions, and the mean change of -0.7 percent of potential GDP has a standard error of only 0.2 percent across the six prerecession periods. The mean decline is only slightly greater during recession, although it accounts for much less of the mean decline in GDP or final sales and the standard error is more than four times as large. Residential construction is also strongly procyclical during recoveries, accounting for about twothirds of the increase in final sales. The behavior of this sector is obviously tied closely to the movement of interest rates over the cycle. It is interesting that residential construction has been as cyclical in the later recessions-when the end of deposit ceilings had loosened the channel of influence through disintermediation and variable rate mortgages had been introduced-as it had been in earlier recessions, when interest rate ceilings on time deposits were such an important feature of the financial scene.

Producers' DURABle equipment. Expenditures by businesses on equipment show no systematic cyclical pattern leading up to recessions, although they are systematically procyclical during recession and recovery. During recession, on average, they have accounted for onequarter of the decline in final sales, and with a low standard deviation across recessions.

NONRESIDENTIAL STRUCTURES. Business expenditures on nonresidential structures are in step with the cycle in overall final sales only during the recession quarters. On average, and in most of the recessions studied, nonresidential structures outlays were still rising in the year before the recession when total final sales were declining relative to trend, 
Table 2. Components of Final Sales around Recessions

Change as percent of potential GDP

\begin{tabular}{|c|c|c|c|c|c|c|}
\hline \multirow[b]{2}{*}{ Component } & \multirow[b]{2}{*}{ Recession } & \multicolumn{5}{|c|}{ Interval } \\
\hline & & $\begin{array}{c}(P-4) \\
\text { to } P\end{array}$ & $P$ to $T$ & $\begin{array}{c}T \text { to } \\
(T+5)\end{array}$ & $\begin{array}{c}T \text { to } \\
(T+7)\end{array}$ & $\begin{array}{c}P \text { to } T \\
(a . r .)\end{array}$ \\
\hline \multirow{10}{*}{$\begin{array}{l}\text { Personal } \\
\text { consumption } \\
\text { expenditures }\end{array}$} & $1957: 3-1958: 2$ & -0.5 & -1.5 & 2.2 & 1.6 & -2.0 \\
\hline & $1960: 2-1961: 1$ & -0.1 & -1.4 & 0.6 & 0.8 & -1.8 \\
\hline & $1969: 4-1970: 4$ & -0.3 & -1.2 & 1.1 & 2.2 & -1.2 \\
\hline & $1973: 4-1975: 1$ & -1.1 & -3.3 & 1.9 & 2.5 & -2.7 \\
\hline & $1980: 1-1982: 4$ & -1.4 & -2.0 & 2.3 & 2.8 & -0.7 \\
\hline & 1990:3-1991:1 & -0.6 & -1.8 & -0.4 & 0.4 & -3.6 \\
\hline & Mean (excluding 1990-91) & -0.7 & -1.9 & 1.6 & 2.0 & -1.7 \\
\hline & Mean & -0.7 & -1.9 & 1.3 & 1.7 & -2.0 \\
\hline & Standard deviation & 0.4 & 0.7 & 0.9 & 0.9 & 0.9 \\
\hline & $1990-91$, less mean others & 0.0 & 0.1 & -2.0 & -1.5 & -2.0 \\
\hline \multirow{10}{*}{$\begin{array}{l}\text { Residential } \\
\text { fixed } \\
\text { investment }\end{array}$} & $1957: 3-1958: 2$ & -0.6 & -0.4 & 1.3 & 1.2 & -0.5 \\
\hline & 1960:2-1961:1 & -0.9 & -0.3 & 0.5 & 0.4 & -0.4 \\
\hline & $1969: 4-1970: 4$ & -0.5 & 0.2 & 1.3 & 1.3 & 0.2 \\
\hline & 1973:4-1975:1 & -1.0 & -2.3 & 0.8 & 1.2 & -1.9 \\
\hline & 1980:1-1982:4 & -1.0 & -2.0 & 1.2 & 1.2 & -0.7 \\
\hline & 1990:3-1991:1 & -0.6 & -0.6 & 0.4 & 0.6 & -1.2 \\
\hline & Mean (excluding 1990-91) & -0.8 & -0.9 & 1.0 & 1.0 & -0.6 \\
\hline & Mean & -0.7 & -0.9 & 0.9 & 1.0 & -0.7 \\
\hline & Standard deviation & 0.2 & 0.9 & 0.4 & 0.4 & 0.7 \\
\hline & $1990-91$, less mean others & 0.2 & 0.3 & -0.6 & -0.5 & -0.5 \\
\hline \multirow{10}{*}{$\begin{array}{l}\text { Producers' } \\
\text { durable } \\
\text { equipment }\end{array}$} & 1957:3-1958:2 & -0.0 & -1.2 & 0.5 & 0.5 & -1.6 \\
\hline & 1960:2-1961:1 & 0.1 & -0.7 & 0.5 & 0.3 & -0.9 \\
\hline & $1969: 4-1970: 4$ & -0.1 & -0.5 & 0.2 & 0.5 & -0.5 \\
\hline & 1973:4-1975:1 & 0.5 & -1.3 & -0.1 & 0.1 & -1.0 \\
\hline & $1980: 1-1982: 4$ & -0.4 & -1.6 & 0.9 & 1.3 & -0.6 \\
\hline & 1990:3-1991:1 & -0.2 & -0.5 & 0.3 & 0.6 & -1.1 \\
\hline & Mean (excluding 1990-91) & 0.0 & -1.1 & 0.4 & 0.5 & -0.9 \\
\hline & Mean & 0.0 & -1.0 & 0.4 & 0.6 & -1.0 \\
\hline & Standard deviation & 0.3 & 0.4 & 0.3 & 0.3 & 0.4 \\
\hline & $1990-91$, less mean others & -0.2 & 0.5 & -0.1 & 0.1 & -0.1 \\
\hline \multirow{10}{*}{$\begin{array}{l}\text { Nonresidential } \\
\text { structures }\end{array}$} & $1957: 3-1958: 2$ & -0.2 & -0.3 & 0.1 & 0.1 & -0.5 \\
\hline & 1960:2-1961:1 & 0.2 & 0.1 & -0.0 & -0.1 & 0.1 \\
\hline & 1969:4-1970:4 & 0.1 & -0.3 & -0.1 & -0.1 & -0.3 \\
\hline & $1973: 4-1975: 1$ & 0.2 & -0.7 & -0.2 & -0.2 & -0.6 \\
\hline & 1980:1-1982:4 & 0.3 & -0.3 & -0.1 & 0.2 & -0.1 \\
\hline & 1990:3-1991:1 & -0.0 & -0.3 & -0.5 & -0.6 & -0.7 \\
\hline & Mean (excluding 1990-91) & 0.1 & -0.3 & -0.1 & 0.0 & -0.3 \\
\hline & Mean & 0.1 & -0.3 & -0.1 & -0.1 & -0.3 \\
\hline & Standard deviation & 0.2 & 0.2 & 0.2 & 0.3 & 0.3 \\
\hline & $1990-91$, less mean others & -0.1 & 0.0 & -0.4 & -0.6 & -0.4 \\
\hline
\end{tabular}


Table 2. (continued)

Change as percent of potential GDP

\begin{tabular}{|c|c|c|c|c|c|c|}
\hline \multirow[b]{2}{*}{ Component } & \multirow[b]{2}{*}{ Recession } & \multicolumn{5}{|c|}{ Interval } \\
\hline & & $\begin{array}{c}(P-4) \\
\text { to } P\end{array}$ & $P$ to $T$ & $\begin{array}{c}T \text { to } \\
(T+5)\end{array}$ & $\begin{array}{c}T \text { to } \\
(T+7)\end{array}$ & $\begin{array}{c}\text { P to } T \\
\text { (a.r.) }\end{array}$ \\
\hline \multirow{10}{*}{$\begin{array}{l}\text { Imports } \\
\text { (sign reversed) }\end{array}$} & $1957: 3-1958: 2$ & 0.1 & -0.2 & -0.3 & -0.2 & -0.3 \\
\hline & 1960:2-1961:1 & 0.1 & 0.5 & -0.4 & -0.4 & 0.6 \\
\hline & 1969:4-1970:4 & -0.2 & 0.1 & -0.7 & -0.5 & 0.1 \\
\hline & 1973:4-1975:1 & 0.1 & 1.4 & -0.7 & -1.1 & 1.1 \\
\hline & 1980:1-1982:4 & 0.1 & 0.7 & -2.0 & -2.5 & 0.3 \\
\hline & 1990:3-1991:1 & -0.1 & 0.8 & -1.1 & -1.5 & 1.7 \\
\hline & Mean (excluding 1990-91) & 0.1 & 0.5 & -0.8 & -0.8 & 0.4 \\
\hline & Mean & 0.0 & 0.6 & -0.9 & -0.9 & 0.6 \\
\hline & Standard deviation & 0.1 & 0.5 & 0.6 & 0.9 & 0.7 \\
\hline & $1990-91$, less mean others & -0.2 & 0.3 & -0.3 & -0.8 & 1.3 \\
\hline \multirow[t]{10}{*}{ Exports } & $1957: 3-1958: 2$ & 0.1 & -0.8 & 0.1 & 0.4 & -1.0 \\
\hline & 1960:2-1961:1 & 0.6 & 0.0 & 0.1 & -0.1 & 0.0 \\
\hline & 1969:4-1970:4 & 0.2 & 0.1 & -0.0 & 0.1 & 0.1 \\
\hline & 1973:4-1975:1 & 0.8 & 0.1 & -0.1 & 0.1 & 0.1 \\
\hline & 1980:1-1982:4 & 0.6 & -1.6 & 0.2 & 0.4 & -0.6 \\
\hline & 1990:3-1991:1 & 0.5 & 0.0 & 0.6 & 1.0 & 0.1 \\
\hline & Mean (excluding 1990-91) & 0.5 & -0.4 & 0.1 & 0.2 & -0.3 \\
\hline & Mean & 0.5 & -0.3 & 0.2 & 0.3 & -0.2 \\
\hline & Standard deviation & 0.2 & 0.6 & 0.2 & 0.4 & 0.4 \\
\hline & 1990-91, less mean others & 0.0 & 0.4 & 0.6 & 0.9 & 0.3 \\
\hline \multirow{10}{*}{$\begin{array}{l}\text { State and local } \\
\text { purchases }\end{array}$} & $1957: 3-1958: 2$ & 0.2 & 0.3 & 0.1 & 0.0 & 0.4 \\
\hline & 1960:2-1961:1 & -0.1 & 0.4 & -0.2 & -0.2 & 0.5 \\
\hline & 1969:4-1970:4 & -0.3 & 0.1 & -0.1 & -0.3 & 0.1 \\
\hline & 1973:4-1975:1 & -0.1 & -0.1 & -0.3 & -0.6 & -0.1 \\
\hline & 1980:1-1982:4 & 0.0 & -0.8 & 0.0 & 0.0 & -0.3 \\
\hline & 1990:3-1991:1 & 0.1 & 0.0 & -0.1 & -0.1 & -0.1 \\
\hline & Mean (excluding 1990-91) & -0.1 & 0.0 & -0.1 & -0.2 & 0.1 \\
\hline & Mean & 0.0 & 0.0 & -0.1 & -0.2 & 0.1 \\
\hline & Standard deviation & 0.2 & 0.4 & 0.1 & 0.2 & 0.3 \\
\hline & 1990-91, less mean others & 0.1 & 0.0 & 0.0 & 0.0 & -0.2 \\
\hline \multirow{10}{*}{$\begin{array}{l}\text { Federal } \\
\text { purchases }\end{array}$} & $1957: 3-1958: 2$ & 0.3 & -0.7 & -0.9 & -1.8 & -0.9 \\
\hline & 1960:2-1961:1 & -1.1 & 0.0 & 0.6 & 0.2 & 0.0 \\
\hline & 1969:4-1970:4 & -1.0 & -1.5 & -1.0 & -1.5 & -1.5 \\
\hline & 1973:4-1975:1 & -0.9 & -0.2 & -0.4 & -0.5 & -0.2 \\
\hline & 1980:1-1982:4 & 0.0 & 0.4 & 0.0 & 0.0 & 0.1 \\
\hline & 1990:3-1991:1 & -0.2 & 0.2 & -0.6 & -0.6 & 0.4 \\
\hline & Mean (excluding 1990-91) & -0.5 & -0.4 & -0.3 & -0.7 & -0.5 \\
\hline & Mean & -0.5 & -0.3 & -0.4 & -0.7 & -0.3 \\
\hline & Standard deviation & 0.6 & 0.6 & 0.6 & 0.7 & 0.7 \\
\hline & 1990-91, less mean others & 0.3 & 0.6 & -0.3 & 0.1 & 0.9 \\
\hline
\end{tabular}

Source: Authors' calculations based on CBO estimates and NIPA. 
and were still falling relative to trend in the recovery quarters. In the most recent recession, the widely advertised overbuilding of commercial and office structures showed up as only a modest departure from the average performance of this sector in the quarters leading up to the recession and as no departure from average during the recession itself. But during the recovery, nonresidential construction has declined relative to trend by 0.6 percent of GDP, compared with no change in the previous five recessions.

EXPORTS AND IMPORTS. Foreign trade has, on balance, been countercyclical around recessions. Imports, shown with sign reversed in table 2 so as to represent their contribution to GDP, fell relative to trend during recession, rose during recovery, and changed little in the year before the peak. Exports rose relative to trend except during recession, where the mean performance was dominated by sharp declines in the recessions starting in 1957 and 1980, when there were coincident recessions in the rest of the industrial world. Surprisingly, exports did not decline in the 1973-75 recession, which also had counterparts abroad. Taken together, exports and imports have supported final sales before and during recessions, and retarded the recovery phase of the cycles. The recent recession has followed this typical pattern.

GOVERNMENT PURCHASES. The only important contribution of government purchases to the recession episodes has been the fairly persistent tendency of federal purchases to decline relative to trend. However, there is considerable variation across the different recessions and the mean is never as large as the standard error for either state and local purchases or federal purchases. The absence of any countercyclical behavior of federal purchases presumably reflects the sporadic impact of changes in defense budgets, and the long delays in using purchases as a response to recessions, as well as the use of increased transfers-and, occasionally, tax changes-instead.

INFERENCES FROM COMPONENTS. The systematic importance of residential construction in the weakness of final sales before and during recessions almost surely reflects the importance of monetary policy in causing recessions. This sector accounts for only about 4 percent of final sales, yet accounts for more than one-half the weakness in final sales in the quarters leading to recession. The great importance of consumer spending-which is less striking because consumption is seventeen times as large a sector as homebuilding-could come from shocks or 
Figure 2. Federal Funds Rate, Real Federal Funds Rate, and High-Employment Surplus Ratio, 1955-92 a

Percent

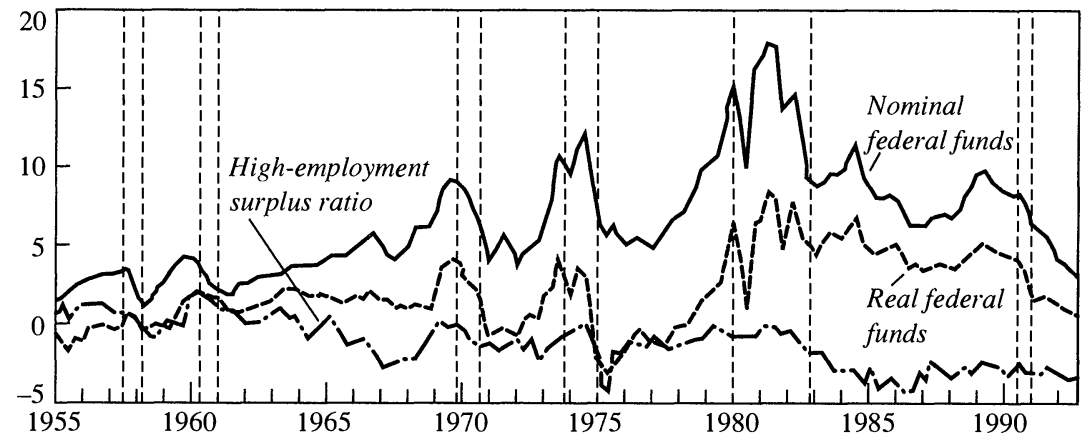

Source: Authors' calculations based on Federal Reserve Bulletin, various issues; NIPA; and CBO estimates. a. The vertical lines are NBER-dated business cycle peaks and troughs. The high-employment surplus ratio is shown as a four-quarter moving average and is expressed as a percent of potential GDP. The real federal funds rate is calculated by subtracting the inflation rate in the GDP deflator over the four most recent quarters from the nominal fed funds rate.

from policy, but its importance also shows that consumer spending around recessions is much more responsive to current developments than many theories would predict. The systematic weakness of business investment during recessions also shows a high responsiveness of business decisions to current developments.

\section{Policy around Recessions}

Some measures of policy variations since 1955 are shown in figure 2 . Fiscal policy is summarized by the high employment surplus, as measured by the Congressional Budget Office, expressed as a percent of potential GDP. A four-quarter moving average is used to smooth out abrupt changes in the $\mathrm{CBO}$ quarterly data. Monetary policy is characterized by the federal funds rate, which is shown both as a nominal rate and as a real rate derived by subtracting the inflation rate in the GDP deflator over the most recent four quarters. We believe the funds rate represents a useful characterization of Federal Reserve policy and is a variable that the Fed can control and set where it wants.

We do not look at various measures of the money supply as a way to characterize policy because of the notorious instability of alternative money measures in relation to other economic variables. This instability, in turn, has kept the Federal Reserve from using money measures as 
a policy instrument during most of the period. The instability is illustrated in appendix table A1, where we present the percent changes in M2 velocity over five recession subperiods. The standard errors in velocity across recessions are typically more than half as large as the standard errors of GDP itself. Interest rates cannot account for this irregularity because interest rate variations across recessions are at least somewhat similar.

One period poses some problems for our characterization of policy. At the end of 1979 and into the early 1980s, Fed policy was related more closely to monetary aggregates so that the behavior of the federal funds rate was more volatile than it would have been under operating procedures that targeted the funds rate directly. But in general, we interpret movements in the funds rate as movements that the Fed chose to make.

Monetary policy has tightened, usually sharply, in the quarters leading up to peaks before every recession except the last one. In this last episode, the funds rate was raised by a full three percentage points during 1988 and the first half of 1989, but it was then gradually reduced by 1.5 points up to the cyclical peak. The picture of monetary policy is no different in terms of real, rather than nominal, interest rates. This is readily apparent in figure 2 and is equally true if real rates are calculated using inflation over the past eight quarters or even twelve quarters. Over intervals relevant for recession analysis, movements in nominal and real interest rates have been dominated by the variations in nominal rates.

Over longer periods of time, where the gap between real and nominal rates has varied, real rates are the more informative variable for most purposes. In particular, the effect on real interest rates of persistent differences in the high employment surplus is apparent from the relation between the two near the peaks preceding the six recessions. The correlation between the real rate and the surplus in the four quarters before peaks is -0.75 across the six recessions. A regression of these observations shows that a 1 percent higher surplus ratio predicts a 1 point lower real federal funds rate in the long run.

The high employment surplus ratio varies less systematically in relation to recessions than the funds rate. Although it has often been discussed as a countercyclical tool, its behavior is importantly influenced by other events and priorities. Major variations in the surplus ratio have been associated with wars and their aftermaths. Even when economic stabilization is considered in budget-making, the process of debating 
and legislating changes and, subsequently, of implementing them may move the timing of fiscal changes away from their countercyclical purpose. As table 2 showed, federal purchases have declined on average relative to GDP before, during, and after recessions. Nonetheless, some countercyclical behavior appears in the surplus ratio around recessions in figure 1 . The decline in the surplus ratio between the early and mid1980 s is also apparent.

\section{Regressions Explaining Recessions}

The preceding discussion has characterized recessions by the performance of the overall economy and individual sectors relative to trend. We now turn to how recessions look against predicted values from equations. Our choice of specification and technique is a compromise between imposing a minimum of priors, as is done in vector autoregressions, and looking hard for the variables and specifications that would maximize the explained variance. Throughout, we explain the change in the logs of variables using as few lagged values of the dependent variable and the minimum number of other explanatory variables as seem to be relevant.

\section{Policy Regressions}

First we look at regressions, shown in table 3 , that explain the change in the log of GDP using only the lagged dependent variable and lags on the two policy variables: the change in the high employment surplus ratio and the change in the federal funds rate. Estimates are shown both for the full sample and for a subsample, which we discuss below, limited to quarters preceding, during, and following recessions. The most obvious source of bias in equations of this form would be from the reaction of policymakers to GDP changes; because these should have the opposite sign, the bias from this source should, if anything, move our estimates toward zero. For example, as GDP declines, for whatever reason, monetary policy can be expected to lower interest rates, leading to a positive correlation over some interval. Estimating with lags on the policy variables minimizes this problem.

We first experimented with the number of lags to include. The fit improved noticeably when the number was increased from three to eight 
Table 3. Explaining Real Output Relative to Trend with Policy Variables, 1956-92 ${ }^{\text {a }}$

\begin{tabular}{|c|c|c|c|c|c|c|c|}
\hline \multirow[b]{2}{*}{ Equation } & \multirow[b]{2}{*}{ Sample } & \multicolumn{4}{|c|}{ Independent variables } & \multicolumn{2}{|c|}{$\begin{array}{c}\text { Summary } \\
\text { statistic }\end{array}$} \\
\hline & & Constant & $\begin{array}{c}\text { Lagged } \\
\text { dependent }\end{array}$ & $\begin{array}{c}\text { High } \\
\text { employment } \\
\text { surplus }^{\mathrm{b}}\end{array}$ & $\begin{array}{c}\text { Federal } \\
\text { funds rate }\end{array}$ & $\bar{R}^{2}$ & $\begin{array}{l}\text { Durbin- } \\
\text { Watson }\end{array}$ \\
\hline $3-1$ & Full sample & $\begin{array}{c}-0.0002 \\
(-0.273)\end{array}$ & $\begin{array}{l}0.379(4) \\
(3.777)\end{array}$ & $\begin{array}{l}-0.655(8) \\
(-2.644)\end{array}$ & $\begin{array}{l}-0.680(6) \\
(-5.758)\end{array}$ & 0.235 & 2.00 \\
\hline $3-2$ & Recessions only & $\begin{array}{c}-0.0010 \\
(-0.273)\end{array}$ & $\begin{array}{l}0.317(4) \\
(2.442)\end{array}$ & $\begin{array}{l}-1.104(8) \\
(-1.974)\end{array}$ & $\begin{array}{l}-0.668(6) \\
(-4.325)\end{array}$ & 0.243 & 2.06 \\
\hline
\end{tabular}

Source: Authors' calculations based on NIPA; Federal Reserve Bulletin, various issues; and CBO estimates. a. The dependent variable is the change in the log of real GDP minus the change in the log of potential GDP. The coefficient shown is the sum of the coefficients on the lagged values; the number of lagged values is given in the parentheses after the coefficient. The $t$-statistic below each coefficient is for the sum of the lagged coefficients.

b. The high-employment surplus ratio and federal funds rate are expressed as first differences.

on all variables, and even up to twelve quarters on the surplus ratio. But the individual coefficient estimates on successive lags varied erratically and the long-run effects of the federal funds rate, calculated by solving for the steady-state change, seemed unrealistically large. We recognize that, with several lagged variables, the coefficients may not be easy to interpret. But we also feared that, given so much freedom to choose, the regression would "cherry-pick" from a few stray observations and do better than it should. Also, when the real funds rate, defined as in figure 2 , replaced the nominal funds rate, the fit deteriorated markedly. And when inflation was added, in various forms, along with the funds rate, its coefficient was erratic and generally insignificant.

For all these reasons, we chose to focus on equations, shown in table 3 , that allow four lags on the lagged dependent, six lags on the funds rate, and eight lags on the surplus ratio. Estimates are shown both for the full sample (3-1) and for a subsample confined to the quarters around recessions (3-2), which we discuss below. Here and throughout, the number in parentheses following the coefficient estimate indicates the numbers of quarters of lagged values that are used; the coefficient shown is the sum of the coefficients on those lagged values, and the $t$-statistics refer to the sum of the lagged coefficients. The lagged coefficients in this specification did not vary erratically and they conformed roughly to our priors that fiscal policy works with the longest lags. Also, the long-run impacts of policy seemed reasonable in the full-sample estimates of equation 3-1, with a 1 percent rise in the surplus ratio or a one point rise in the funds rate each producing a 1.1 percent decline in GDP. 
The possible reaction of policy to nonpolicy shocks, apart from the effects of these shocks on GDP, presents another potential source of bias in the estimates, and bias from this source could be in either direction. The clearest examples are the two OPEC oil price shocks, each of which preceded a recession. Even with accommodating policies, these shocks might have depressed real GDP by shifting real income to oil producers in the United States and abroad with low propensities to spend on U.S. production. If policy reacted to these shocks by tightening, presumably to head off an escalation of overall inflation that might follow from sharply higher oil prices, policy also would depress real GDP. In such a case, our regressions will credit both effects to the policy change that is correlated with the outside shock. The opposite correlation and bias would arise if shocks that would themselves boost GDP are correlated with tightening policy.

Because we cannot hope to model the contribution of all such nonpolicy shocks, we interpret the policy regressions of table 3 as providing estimates of the contribution of policy changes to the cycle. By examining the residuals, we can help gauge how much of the cycle is left to be explained by nonpolicy shocks and endogenous dynamics that are not captured in the lagged dependent variable. The strength and significance of both the fiscal and monetary policy variables is a robust finding in the regressions of table 3 , as well as in the regressions not reported that used different lags on the same explanatory variable.

Equation 3-2 is estimated over just the periods between $\mathrm{P}-4$ and $\mathrm{T}+4$ around each recession. This recession sample contains 84 of the 146 total observations in our data period. The same regression fit to the remaining sixty-two observations produced nonsensical results with a negative adjusted $R^{2}$. If we were to offer a model to motivate our focus on the recession subsample, it would be based on endogenous changes in expectations during and around recessions. But rather than elaborate on such a model, we simply note that the data justify using the recession subsample.

\section{Predicting Recessions and Recoveries}

We next examine how well this policy equation explains recessions by looking at its predictions and errors. These results are summarized in table 4 where, for the intervals from $\mathrm{P}-4$ to $\mathrm{T}$ and from $\mathrm{T}$ to $\mathrm{T}+5$, we 
Table 4. Variations in GDP Due to Policy Variables and to Other Factors

Change as percent of potential GDP

\begin{tabular}{llc}
\hline & \multicolumn{2}{c}{ Interval } \\
\cline { 2 - 3 } Sample and statistic & $(P-4)$ to $T$ & T to $(T+5)$ \\
\hline Mean recession excluding 1990-91 & & \\
Actual & -7.0 & 3.2 \\
Due to policy & -6.5 & 2.5 \\
Due to other & -0.5 & 0.7 \\
1990-91 recession & & \\
Actual & -4.2 & -0.6 \\
Due to policy & -1.4 & 1.8 \\
Due to other & -2.8 & -2.4 \\
1990-91 less mean excluding 1990-91 & & \\
Actual & 2.7 & -3.8 \\
Due to policy & 5.1 & -0.7 \\
Due to other & -2.4 & -3.1 \\
\hline
\end{tabular}

Source: Based on authors' calculations. Actual values are from table 1. "Due to policy" is the dynamic prediction, starting at $\mathrm{P}-4$, and again at T, from the "recessions only" regression, equation 3-2 in table 3 (change over each interval in the sum of $\Delta \log$ predictions). "Due to other" is the difference between actual and "due to policy."

show three statistics. "Actual" is the change shown in table 1, "due to policy" is the change predicted by equation 3-2 in table 3 , and "due to other" is the difference, the prediction error that we attribute to other shocks or to the inability of the policy equation to accurately model the dynamics of recessions. As in previous tables, the units are change in GDP relative to trend as a percent of potential GDP. Because the entries are the sums of changes in logs, they represent the error in the prediction of the levels of the variables starting from the initial level at $\mathrm{P}-4$ for the first column of data, and starting from the initial level at $\mathrm{T}$ for the second column of data.

For recessions before the last one, policy changes, on average, account for a large fraction of the actual change in GDP both up to and following the recession troughs. On average, downturns are worse and recoveries are stronger than the equation predicts, but the mean prediction error is well under 1 percent of GDP at the end of both intervals. In the recent recession, in contrast, actual GDP is 2.8 percent below prediction at the trough. And in the five subsequent quarters of recovery, GDP falls an additional 2.4 percent below prediction. Thus when the contributions of policy changes are taken into account, the 
economy during the recent recession and recovery was exceptionally weak not only during the early recovery phase, as the actual data of table 1 reveal, but over the previous seven quarters, as well.

\section{Regressions for Individual Sectors}

To look further at the behavior of GDP during recessions, and during the latest recession in particular, we turn to regressions for major components of final sales, taking a pragmatic view of how to specify those equations. We do not try to get the best possible fit, as a short-term forecasting exercise might achieve by using preflow data, such as orders for durable goods, permits for new housing, or consumer sentiment. Nor do we limit ourselves to a highly restricted set of explanatory variables, such as the policy set described above. Rather we use what we regard as a parsimonious specification for each sector, but one that makes use of our priors about what is important in determining short-run behavior of individual sectors. Monetary policy, in the form of the federal funds rate, appears explicitly in some equations. Fiscal policy, measured by the high employment surplus, is included indirectly because we use income after taxes and transfers as explanatory variables for some private sectors.

Table 5 summarizes the equations estimated, as before, over the recession subsample, but this time for several sectors: consumption and a breakdown into durables, nondurables, and services; residential construction; producers' durable equipment (PDE); nonresidential construction; state and local government spending; and imports. We found no useful equation for estimating exports or federal purchases in the context of our recession analysis. Some of the equations in table 5 were fit using polynomial distributed lags, with the number of lags chosen after looking first at equations with the same variables, but with four lags on each.

We are interested in the equations primarily for what they fail to predict in the quarters around recessions. We get at this in table 6, which shows the sum of static residuals from the table 5 regressions, using a similar format and expressed in the same units as table 2. Looking at the mean for all recessions, spending is generally overpredicted in the prerecession and recession quarters and underpredicted during the early re- 


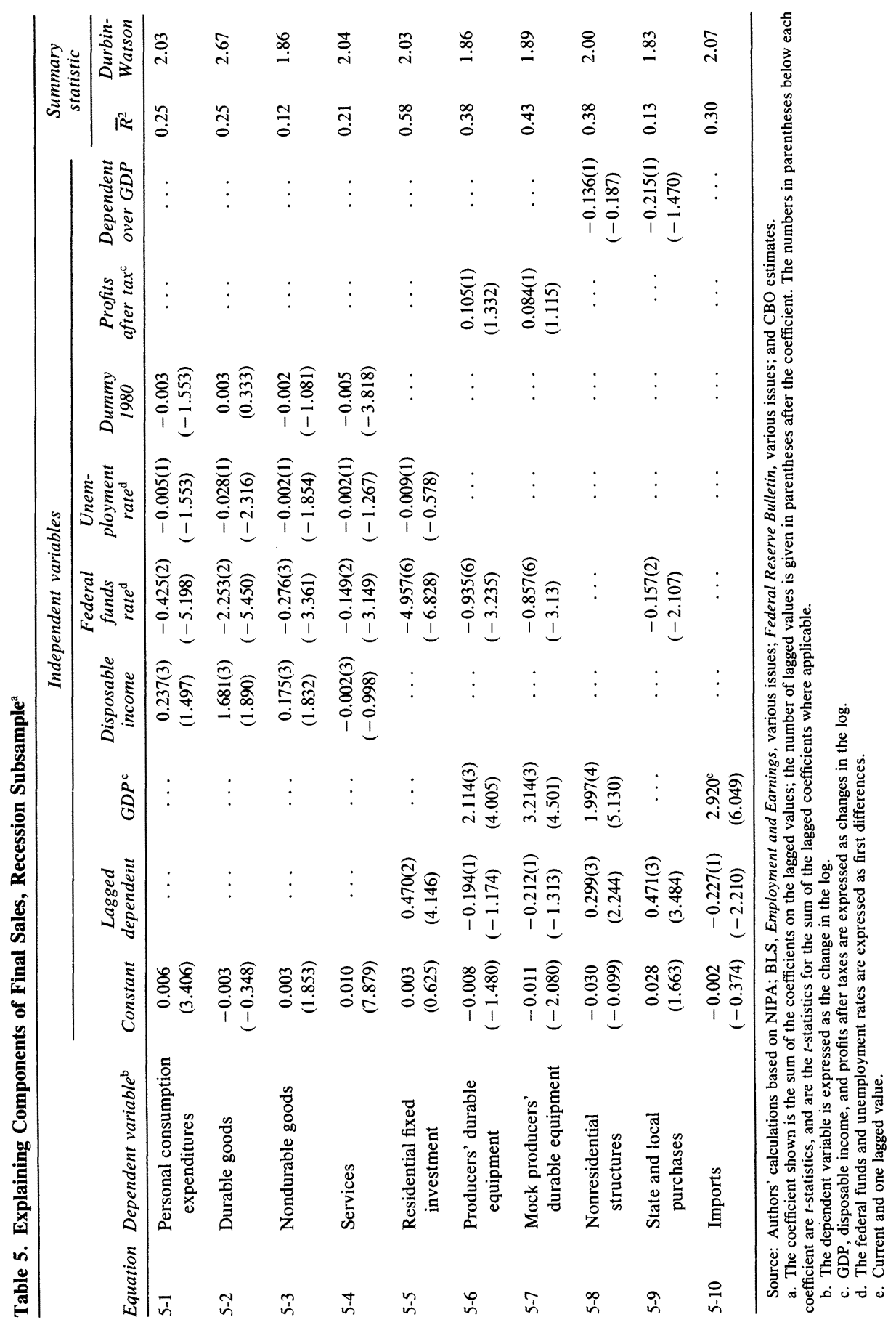


Table 6. Prediction Errors for Components of Final Sales

Change as percent of potential GDP

\begin{tabular}{|c|c|c|c|c|c|c|}
\hline \multirow[b]{2}{*}{ Component } & \multirow[b]{2}{*}{ Recession } & \multicolumn{5}{|c|}{ Interval } \\
\hline & & $\begin{array}{c}(P-4) \\
\text { to } P \\
\end{array}$ & $P$ to $T$ & $\begin{array}{c}T \text { to } \\
(T+5)\end{array}$ & $\begin{array}{c}P \text { to } T \\
(a . r .)\end{array}$ & $\begin{array}{c}(P-4) \\
t o \\
(T+5) \\
\end{array}$ \\
\hline Consumption & $\begin{array}{l}\text { Mean } \\
\text { 1990-91 recession } \\
\text { Mean other recessions } \\
\text { Standard deviation (all) } \\
\text { 1990-91, less mean others }\end{array}$ & $\begin{array}{r}-0.1 \\
-0.7 \\
0.0 \\
0.5 \\
-0.8\end{array}$ & $\begin{array}{r}-0.8 \\
-1.4 \\
-0.7 \\
0.6 \\
-0.7\end{array}$ & $\begin{array}{r}0.7 \\
0.0 \\
0.8 \\
0.4 \\
-0.8\end{array}$ & $\begin{array}{r}-1.1 \\
-2.8 \\
-0.8 \\
0.9 \\
-2.0\end{array}$ & $\begin{array}{r}-0.2 \\
-2.1 \\
0.2 \\
-2.3\end{array}$ \\
\hline Durable goods & $\begin{array}{l}\text { Mean } \\
\text { 1990-91 recession } \\
\text { Mean other recessions } \\
\text { Standard deviation (all) } \\
\text { 1990-91, less mean others }\end{array}$ & $\begin{array}{r}-0.2 \\
-0.8 \\
-0.1 \\
0.3 \\
-0.7\end{array}$ & $\begin{array}{r}-0.2 \\
-0.5 \\
-0.2 \\
0.4 \\
-0.3\end{array}$ & $\begin{array}{r}0.3 \\
0.1 \\
0.4 \\
0.2 \\
-0.2\end{array}$ & $\begin{array}{r}-0.4 \\
-0.9 \\
-0.3 \\
0.4 \\
-0.7\end{array}$ & $\begin{array}{r}-0.1 \\
-1.1 \\
0.1 \\
-1.2\end{array}$ \\
\hline Nondurable goods & $\begin{array}{l}\text { Mean } \\
\text { 1990-91 recession } \\
\text { Mean other recessions } \\
\text { Standard deviation (all) } \\
\text { 1990-91, less mean others }\end{array}$ & $\begin{array}{r}0.1 \\
-0.1 \\
0.1 \\
0.2 \\
-0.3\end{array}$ & $\begin{array}{r}-0.3 \\
-0.4 \\
-0.3 \\
0.3 \\
-0.1\end{array}$ & $\begin{array}{r}0.2 \\
-0.1 \\
0.2 \\
0.3 \\
-0.3\end{array}$ & $\begin{array}{r}-0.4 \\
-0.8 \\
-0.3 \\
0.3 \\
-0.5\end{array}$ & $\begin{array}{r}0.0 \\
-0.6 \\
0.1 \\
-0.7\end{array}$ \\
\hline Services & $\begin{array}{l}\text { Mean } \\
\text { 1990-91 recession } \\
\text { Mean other recessions } \\
\text { Standard deviaticn (all) } \\
\text { 1990-91, less mean others }\end{array}$ & $\begin{array}{l}0.0 \\
0.1 \\
0.0 \\
0.2 \\
0.1\end{array}$ & $\begin{array}{r}-0.3 \\
-0.6 \\
-0.2 \\
0.3 \\
-0.4\end{array}$ & $\begin{array}{r}0.2 \\
-0.1 \\
0.2 \\
0.2 \\
-0.3\end{array}$ & $\begin{array}{r}-0.3 \\
-1.1 \\
-0.2 \\
0.4 \\
-0.9\end{array}$ & $\begin{array}{r}-0.1 \\
-0.5 \\
0.0 \\
-0.5\end{array}$ \\
\hline $\begin{array}{l}\text { Residential fixed } \\
\text { investment }\end{array}$ & $\begin{array}{l}\text { Mean } \\
\text { 1990-91 recession } \\
\text { Mean other recessions } \\
\text { Standard deviation (all) } \\
\text { 1990-91, less mean others }\end{array}$ & $\begin{array}{r}-0.1 \\
-0.6 \\
0.0 \\
0.3 \\
-0.6\end{array}$ & $\begin{array}{r}-0.2 \\
-0.4 \\
-0.2 \\
0.5 \\
-0.2\end{array}$ & $\begin{array}{r}0.2 \\
0.0 \\
0.2 \\
0.2 \\
-0.2\end{array}$ & $\begin{array}{r}-0.2 \\
-0.8 \\
-0.1 \\
0.5 \\
-0.7\end{array}$ & $\begin{array}{r}-0.1 \\
-1.0 \\
0.0 \\
-1.0\end{array}$ \\
\hline $\begin{array}{l}\text { Producers' } \\
\text { durable equipment }\end{array}$ & $\begin{array}{l}\text { Mean } \\
\text { 1990-91 recession } \\
\text { Mean other recessions } \\
\text { Standard deviation (all) } \\
\text { 1990-91, less mean others }\end{array}$ & $\begin{array}{r}0.0 \\
-0.1 \\
0.1 \\
0.1 \\
-0.2\end{array}$ & $\begin{array}{r}-0.1 \\
-0.2 \\
-0.1 \\
0.4 \\
-0.2\end{array}$ & $\begin{array}{l}0.1 \\
0.4 \\
0.0 \\
0.2 \\
0.4\end{array}$ & $\begin{array}{r}-0.3 \\
-0.5 \\
-0.2 \\
0.4 \\
-0.2\end{array}$ & $\begin{array}{l}0.0 \\
0.1 \\
0.0 \\
0.0\end{array}$ \\
\hline $\begin{array}{l}\text { Mock producers' } \\
\text { durable equipment }\end{array}$ & $\begin{array}{l}\text { Mean } \\
\text { 1990-91 recession } \\
\text { Mean other recessions } \\
\text { Standard deviation (all) } \\
\text { 1990-91, less mean others }\end{array}$ & $\begin{array}{r}0.0 \\
-0.2 \\
0.1 \\
0.1 \\
-0.3\end{array}$ & $\begin{array}{r}-0.1 \\
-0.3 \\
0.0 \\
0.5 \\
-0.2\end{array}$ & $\begin{array}{l}0.1 \\
0.2 \\
0.0 \\
0.2 \\
0.1\end{array}$ & $\begin{array}{r}-0.3 \\
-0.6 \\
-0.2 \\
0.4 \\
-0.4\end{array}$ & $\begin{array}{r}0.0 \\
-0.4 \\
0.1 \\
-0.5\end{array}$ \\
\hline $\begin{array}{l}\text { Nonresidential } \\
\text { structures }\end{array}$ & $\begin{array}{l}\text { Mean } \\
\text { 1990-91 recession } \\
\text { Mean other recessions } \\
\text { Standard deviation (all) } \\
\text { 1990-91, less mean others }\end{array}$ & $\begin{array}{l}0.0 \\
0.0 \\
0.0 \\
0.1 \\
0.0\end{array}$ & $\begin{array}{r}0.0 \\
-0.2 \\
0.1 \\
0.2 \\
-0.3\end{array}$ & $\begin{array}{r}0.0 \\
-0.1 \\
0.0 \\
0.1 \\
0.0\end{array}$ & $\begin{array}{r}0.0 \\
-0.4 \\
0.0 \\
0.2 \\
-0.4\end{array}$ & $\begin{array}{r}0.0 \\
-0.3 \\
0.1 \\
-0.3\end{array}$ \\
\hline $\begin{array}{l}\text { Imports (sign } \\
\text { reversed) }\end{array}$ & $\begin{array}{l}\text { Mean } \\
\text { 1990-91 recession } \\
\text { Mean other recessions } \\
\text { Standard deviation (all) } \\
\text { 1990-91, less mean others }\end{array}$ & $\begin{array}{r}0.1 \\
-0.1 \\
0.2 \\
0.3 \\
-0.3\end{array}$ & $\begin{array}{r}-0.1 \\
0.1 \\
-0.2 \\
0.4 \\
0.3\end{array}$ & $\begin{array}{r}-0.1 \\
-1.0 \\
0.1 \\
0.5 \\
-1.1\end{array}$ & $\begin{array}{r}-0.1 \\
0.2 \\
-0.1 \\
0.5 \\
0.4\end{array}$ & $\begin{array}{r}-0.1 \\
-1.0 \\
0.1 \\
-1.1\end{array}$ \\
\hline $\begin{array}{l}\text { State and local } \\
\text { purchases }\end{array}$ & $\begin{array}{l}\text { Mean } \\
\text { 1990-91 recession } \\
\text { Mean other recessions } \\
\text { Standard deviation (all) } \\
\text { 1990-91, less mean others }\end{array}$ & $\begin{array}{r}0.0 \\
-0.1 \\
0.0 \\
0.1 \\
-0.1\end{array}$ & $\begin{array}{r}0.1 \\
-0.1 \\
0.1 \\
0.3 \\
-0.2\end{array}$ & $\begin{array}{r}-0.1 \\
0.0 \\
-0.1 \\
0.1 \\
0.1\end{array}$ & $\begin{array}{r}0.1 \\
-0.1 \\
0.2 \\
0.2 \\
-0.3\end{array}$ & $\begin{array}{r}0.0 \\
-0.2 \\
0.0 \\
-0.2\end{array}$ \\
\hline
\end{tabular}

Source: Table 5 equations. These are the changes in the sum of the residuals over the periods shown. 
covery quarters. However, the mean errors for subperiods, now shown to $T+5$ for consistency, are not large alongside the changes in table 2 .

For the most recent recession, the most striking feature revealed by the equation errors in table 6 is the pervasive weakness, revealed by overpredictions, across all sectors (including producers' durable equipment when we look at the mock PDE version discussed below). Across the whole period from $\mathrm{P}-4$ to $\mathrm{T}+5$, all are overpredicted relative to the mean of past recessions. And some are overpredicted relative to past means in each subperiod as well. We turn next to what the data for individual sectors reveal about the latest recession.

CONSUMPTION. Spending by consumers has not only been weak during this recovery, as table 2 showed, but it has been substantially overpredicted relative to earlier recessions in the other subperiods as well, and especially so during the recession itself when the decline is expressed at annual rates. The weakness in total consumption is evident in each of the subcategories of the total, although not always with the same timing. The weakness in durable goods spending was especially marked in the year preceding the recession and in the recession itself when expressed at annual rates. Even in the first year of recovery, the error in durables this time relative to previous recoveries was an overprediction of 0.2 percent of potential GDP, which is an error of about 5 percent of durable goods spending. Spending on services held up before the recession, but was overpredicted thereafter. Within durable goods, the overpredic-tions were concentrated in motor vehicle purchases (not shown). Weakness in consumption was also highlighted in Olivier J. Blanchard's analysis of the recent recession, though his VAR analysis found it concentrated in nondurable goods. ${ }^{4} \mathrm{We}$ also assign more responsibility to nonconsumption sectors than he does.

RESIDENTIAL CONSTRUCTION. Table 2 showed a striking regularity of weak residential construction spending in the quarters before all recessions. Table 6 reveals that in the recent recession, this sector has been overpredicted across each subperiod. Compared to the mean of earlier recessions, residential construction has underperformed by 1.0 percent of GDP over the entire period from $\mathrm{P}-4$ to $\mathrm{T}+5$. This may reflect an exceptional overhang of multifamily structures and some unwillingness to make mortgages in some parts of the market.

4. Blanchard (1992). 
PRODUCERS' DURABLE EQUIPMENT. Comparing the mean errors of table 6 with actual changes from table 2 , spending on producers' durable equipment appears well predicted by the equation. But in the recent recovery, the exceptional rise in PDE spending produced by far the largest error for any period for any recession. It would appear that whatever general forces not captured in the predicting equations depressed consumption and residential construction, they were not at work in this sector.

However, the concentration of investment strength in the high-tech sector of PDE suggests that the special problems with deflating those expenditures may be distorting the measure of activity in the sector. In particular, the part of the surprising increase in PDE that comes from the rapidly declining deflator that is used to take account of technical progress generates no employment and is probably not predictable from conventional equipment demand models. So we investigated how a PDE total, obtained by substituting the deflator for the rest of PDE for the deflator for high-tech equipment, performs in this and earlier recessions. The results are shown in the row for mock PDE in table 6, based on equation 5-7, which has a somewhat better fit over the entire sample period than does 5-6, the equation for official PDE. Compared with other recessions, mock PDE is overpredicted in the pre-recession and recession quarters. Although it is still relatively strong in this recovery, it is not the outlier that the official PDE measure is, with a prediction error of only half the standard deviation across all recoveries.

OTHER SECTORS. The remainder of business fixed investmentnonresidential structures-has been exceptionally weak in this recession; however, because it accounts for only 3 percent of GDP, the overpredictions do not account for much of the overall weakness in GDP. It should be noted that the contrast between this performance and that of PDE does not represent contrary behavior by the same businesses. The weakness in construction is dominated by the commercial and office building sectors, which have been depressed by overcapacity and the unwillingness of financial institutions to extend mortgage financing to the sector in most parts of the country.

There is less to say about the remaining sectors. Imports have alternating positive and negative errors in the subperiods; rising imports in the most recent recovery have been an exceptional drag on GDP relative to other recovery periods, but we have no conjectures about why this is 
so. State and local government spending was also slightly weaker in this recession relative to others, but again we have no conjectures about why. As noted earlier, we offer no equations to explain exports and federal purchases during recessions.

\section{Policy Reactions}

The finding that policy accounts for a good part of the economy's performance around recessions leads naturally to looking for a way to evaluate the conduct of policy and in particular to judge its performance in the latest recession and recovery. Although the equations of table 3 showed that both fiscal and monetary policy were important determinants of GDP around recessions, we focus on monetary policy because, as we discussed earlier, fiscal policy has not been conducted in a systematic way relative to the business cycle. Even for monetary policy, it is difficult to pose the question of how well the Fed has conducted policy around recessions. The Fed has no policy rule with which to control the growth of, say, nominal GDP with much precision, let alone to eliminate both recessions and inflation. Thus in setting policy, the Fed must deal with the economic conditions that exist-which, up to now, has meant reacting countercyclically to both inflation and unemployment and, at times, to clearly evident shocks that have implications for the economy.

Although we find this description of the conduct of monetary policy realistic, it does not lead to a reaction function that adequately describes the Federal Reserve's behavior over time. There are a number of reasons for this. One is that Fed policy cannot be modeled properly in relation to the aforementioned special shocks. Perhaps more important is the changing importance over time that policymakers have attached to inflation and unemployment. When we estimated reaction functions, fit either to our entire sample or to only the recession subsample, changes in the unemployment rate and changes in inflation both had significant coefficients with the expected sign in explaining changes in the federal funds rate. Other variables meant to capture the interaction between levels and changes in inflation were, to our surprise, insignificant. All these equations, on average, substantially underpredicted the rise in the funds rate in the quarters leading up to cyclical peaks and overpredicted, although by a lesser amount, the increase in the funds rate in the quarters following troughs. We conclude that, although monetary policy is potent, and has helped cause recessions as well as aid recoveries, formal 
reaction functions do not characterize the policy process well. Even if they did, they would not provide evidence of whether monetary policy had done its job well or badly.

The recent recession stands out for the high level of real Fed funds with which it started. At P - 4, the real funds rate calculated using fourquarter lagged inflation in the GDP deflator was 4.8 percent, compared with a mean of 0.3 percent in previous recessions. This is high, even allowing for the long-term decline in the surplus ratio and the rule of thumb suggested by equation 3-1 of table 3 , in which a 1 percent decline in the surplus ratio would be offset by about a one point increase in the real funds rate. Comparing the economy across the $\mathrm{P}-4$ quarters preceding all recessions, the real funds rate before the latest recession was 4.5 points above the mean and the surplus ratio was only 1.9 points below the mean. Starting from this high level of the funds rate preceding the last recession, monetary policy was prompt in easing. Nonetheless, at $\mathrm{T}+5$, the real funds rate, at 1.2 percent, was still higher than in any previous recovery except the one following the 1982 trough, a period when inflation dropped precipitously.

Most observers believe the latest recovery has been unnecessarily slow. To blame the Fed for this presumes it should have been able to forecast that outcome, which may be asking too much, or at least that it should have been able to react more promptly and aggressively to the evidence as it emerged. Many observers reasoned that, point estimates aside, the risk was overwhelmingly in doing too little to encourage recovery, especially in light of the scheduled reduction of defense outlays, the widely recognized depression in construction, the weakness in other industrial sectors, and a number of other special problems of both the financial and nonfinancial sectors of the economy-some of which we examine more closely below. As William C. Brainard pointed out long ago, in a world of uncertainty, how vigorously policy should be pursued will depend on how far from the desired level the actual economy is. ${ }^{5}$ At the start of a recovery, GDP is very far from where it should be.

\section{Employment and Consumption}

One of the features of the current recovery that has repeatedly been characterized as different is the lack of employment growth. In this con-

5. Brainard (1967). 
nection, the widely publicized structural reductions in the workforces of numerous U.S. corporations are taken as evidence that corporate downsizing has produced a recovery with uniquely depressed hiring and small employment gains. In view of the large role of weak consumer spending in this recession episode, documented above, weak employment growth, in turn, may have contributed exceptionally to the weakness of aggregate demand. Two questions are at issue. Has employment grown more slowly than expected given the cyclical behavior of the economy? And to the extent that employment has grown more slowly than in previous recoveries, whether for special reasons or because the expansion was weak, has this behavior in turn affected the growth of aggregate demand in a distinctive way?

PRODUCTIVITY. One part of this issue has to do with productivity, as shown in figure 3 . The first panel of the figure confirms that, in comparison with other recoveries, employment growth in the nonfarm business sector has been stagnant over the past several years. But as the second panel of the figure makes clear, output has also grown much more slowly in this recovery. Is the disappointing employment growth simply the consequence of sluggish output growth, or does it also reflect an unexpected improvement in productivity, perhaps related to the recent and well-publicized downsizing and restructuring efforts among many U.S. firms?

Productivity growth over the four quarters of 1992, at 3.2 percent, represented a substantial pickup from the very low pace of 1990 and 1991 , and exceeded by a noticeable margin the 0.85 percent a year trend growth that has characterized the period since 1973 . But productivity has a cyclical component. It typically does poorly relative to trend in recession and picks up in recovery. Changing labor inputs for a firm is a costly process, the extent of the costs depending on a number of factors, including the speed of the change. Labor is not shed proportionately to output during cyclical contractions and the subsequent recovery begins in an environment of "surplus" labor on business payrolls. Some output growth can be accomplished with little or no addition of aggregate hours of labor input. But eventually the slack in the workforce will be eliminated, and further output increases will require additions to aggregate hours of labor input. ${ }^{6}$ These may come from expanded employment. Or,

6. At a microeconomic level, this is a clearly nonlinear process. But because across the economy individual firms start with widely differing degrees of slack and reach the "tipping" point at different times, the aggregate numbers are much smoother. 
Figure 3. Employment and Output, before and after the Trough of Recession Index, trough $=100$
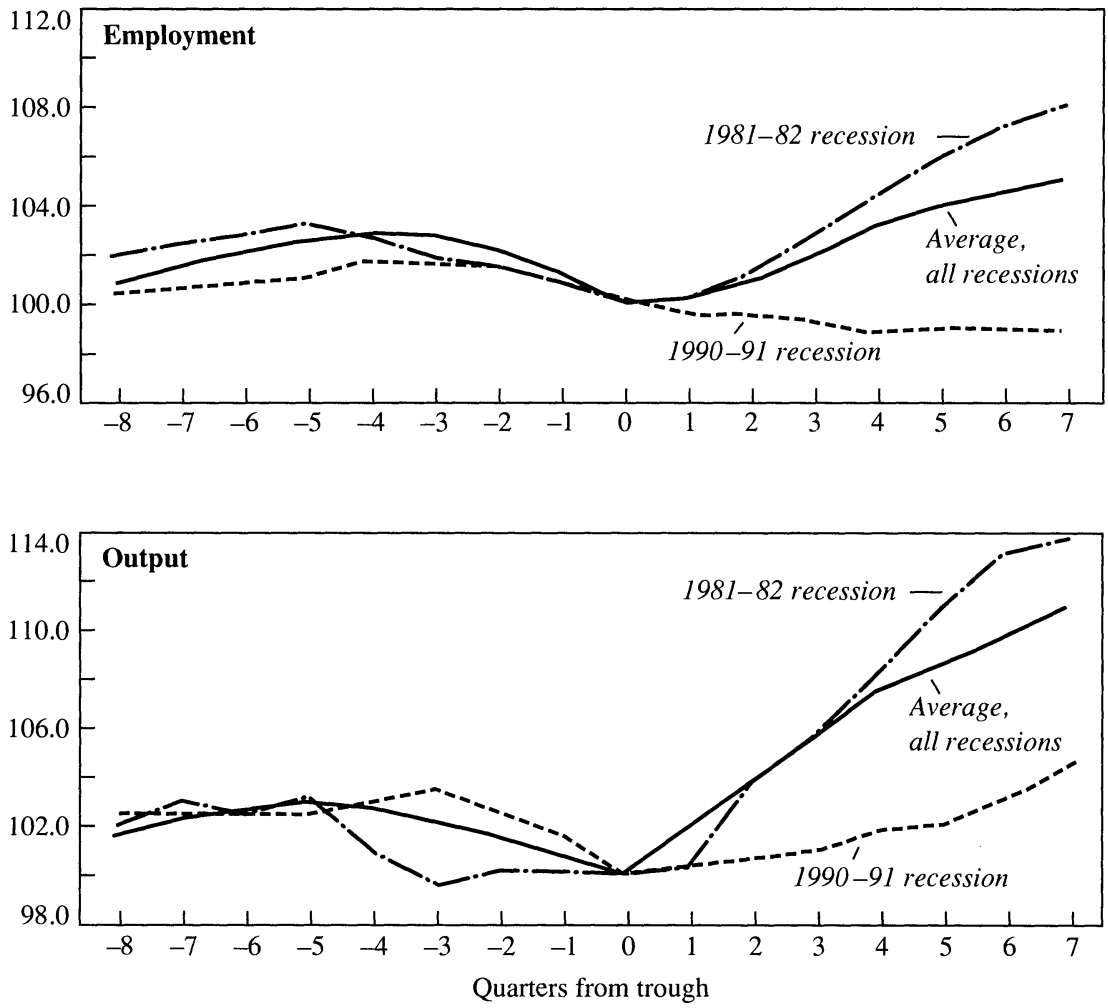

Source: Authors' calculations based on Bureau of Labor Statistics (BLS), Productivity and Costs, various issues, using nonfarm business output and employment.

because of hiring costs, firms that are uncertain about the permanence of improvements in their markets may initially meet additional labor requirements by increasing the length of the workweek; only as they become less uncertain may they substitute new employees for higher average hours. Finally, business firms may consistently overpredict future markets in the latter stages of business cycle expansions, as Robert J. Gordon has proposed. ${ }^{7}$ Firms foresee a continuation of recovery rates of growth, and in response increase labor inputs excessively. A subsequent correction occurs when the recession dashes their optimistic expectations, and the consequent rebound of productivity is independent

7. See Gordon (1984) and his paper in this issue of BPEA. 
Table 7. Productivity and GDP Growth during Recoveries

\begin{tabular}{|c|c|c|c|c|c|c|}
\hline \multirow[b]{2}{*}{$\begin{array}{l}\text { Recession } \\
\text { trough }(T)\end{array}$} & \multirow{2}{*}{$\begin{array}{l}\text { Productivity } \\
\text { deviation } \\
\text { from trend } \\
\text { at trough }\end{array}$} & \multirow{2}{*}{$\begin{array}{l}\text { Number of } \\
\text { quarters } \\
\text { before } \\
\text { productivity } \\
\text { exceeded } \\
\text { trend }(N)^{\mathrm{a}}\end{array}$} & \multirow{2}{*}{$\begin{array}{l}\text { Productivity } \\
\text { change } \\
\text { minus trend } \\
\text { growth } \\
\text { (a.r.) }\end{array}$} & \multirow[b]{2}{*}{$\begin{array}{c}G D P \text { gap at } \\
\text { trough }\end{array}$} & \multicolumn{2}{|c|}{$\begin{array}{c}\text { Change in } G D P \\
\text { gap from } \\
T \text { to } T+N\end{array}$} \\
\hline & & & & & Actual & $\begin{array}{c}\text { Annual } \\
\text { rate }\end{array}$ \\
\hline 1961:1 & -2.5 & 9 & 1.2 & -3.6 & 2.9 & 1.3 \\
\hline $1970: 4$ & -1.3 & 6 & 1.3 & -1.6 & 2.6 & 1.7 \\
\hline 1975:1 & -2.6 & 2 & 7.0 & -6.1 & 1.4 & 2.8 \\
\hline $1982: 4$ & -1.9 & 6 & 1.5 & -8.9 & 6.3 & 4.2 \\
\hline 1991:1 & -2.1 & 6 & 1.6 & -4.0 & -0.1 & 0.0 \\
\hline
\end{tabular}

Source: BLS, Productivity and Costs, various issues (nonfarm business sector) and NIPA.

a. Time trend of quarterly log of productivity with trend breaks in 1967 and 1974 is fit to 1955-89 and extrapolated through 1992.

of a rebound in output. To the extent that such overhiring and its subsequent correction take place, a separate cyclical component is added to short-run productivity changes.

Table 7 examines the productivity record (nonfarm business, output per hour) during recent recoveries. At first glance, the first three columns of data would seem to confirm the conclusion that there has been nothing surprising about productivity behavior in this recovery. Six quarters after the cycle trough in 1992:3, productivity began to exceed the trend that existed prior to the onset of recession. ${ }^{8}$ In two of the prior four recessions, productivity also took six quarters to exceed this trend. Moreover, the annual excess of the actual growth in productivity relative to trend in the current recovery was similar to those two prior recoveries. So far, there is nothing unusual here. But the last two columns of data in the table reveal the striking fact that productivity rebounded past trend despite very modest increases in output. In a model that explains cyclical productivity movements as essentially deriving from adjustment costs and lags in hiring and firing, the extent to which productivity rises and falls relative to trend will depend on the pattern of output increases and decreases. In such a model, the improvement of productivity in this recovery may indeed have contained some noncyclical "surprise" component. On the other hand, to the extent that much of the cyclical rebound in productivity simply represents a correction of the end-of-expansion overhiring, as Gordon suggests, and is not associated

8. A trend was fitted to the log of productivity for the period 1955 to 1989 , with linear splines in 1967 and 1974. That trend was extrapolated through 1992. 
with hiring lags and adjustment costs, the fact that productivity rebounded in 1992 without significant output gains may reflect nothing more than typical cyclical behavior.

We have tried but failed to reach a satisfactory conclusion about whether a productivity surprise has occurred. Robert Gordon, in his paper in this volume, concludes there has been no surprise, and that is probably the best verdict that can be reached with current evidence. But the weak employment gains documented in figure 3 may be significant for understanding the weakness of the recovery in output, even if the sluggish employment does not arise from a productivity surprise.

THRESHOLD EFFECTS IN EMPLOYMENT. To the extent that the endogenous response of aggregate demand to changes in aggregate output and income is reduced when output growth is accompanied by little employment growth, there may be a threshold phenomenon at work depressing consumption. That is, some of the self-feeding and self-reinforcing aspects of an economic recovery may come into effect only as the recovery begins to exceed some minimum rate of growth. A productivity surprise would contribute to such an effect by holding down employment relative to output, but it is not a necessary part of the story.

There are reasons to believe that the actual and perceived degree of employment growth does indeed influence consumer demand in a positive way. During the current recovery, major surveys of consumer attitudes showed disappointing and erratic recovery in pessimistic consumer evaluations of the immediate and expected economic situation. In particular, and in contrast to other recoveries, consumer perceptions that unemployment was likely to increase did not begin to fall in the early stages of recovery. And in fact, unemployment continued to rise through the middle of 1992. Carroll recently presented a "buffer-stock" theory of precautionary saving, in which consumer perceptions that unemployment is likely to increase, along with the existence of high current unemployment, tend to raise consumer saving; his evidence suggested that the sluggishness of consumption spending through the middle of 1992 can be partially traced to such effects. ${ }^{9}$ This is evidence that the absence of self-fulfilling employment expectations from the current recovery, even if they did not come from a productivity surprise, might help explain the weakness of consumption this time.

SPECIAL EMPLOYMENT EFFECTS. In addition to possible threshold

9. Carroll (1992). 
Figure 4. Ratio of Temporary Layoff to Permanent Job Loss Unemployed, 1967:11992:3

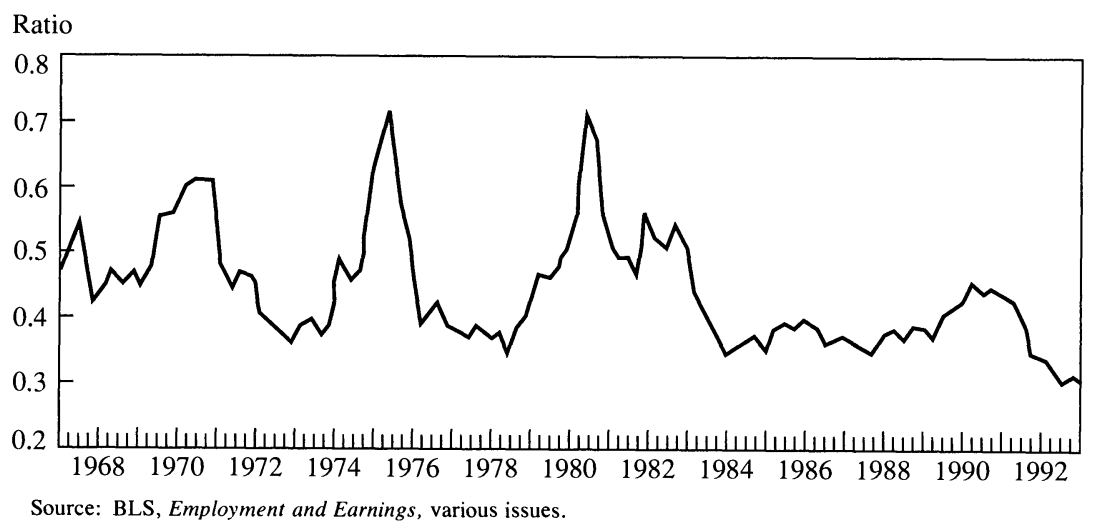

effects from employment growth, other distinctive features of the job market may help explain weak consumption growth in recent years. Indeed, the fact that table 6 showed consumption was weak relative to predictions throughout the latest recession episode, and not only during recovery, suggests the need to look for other causes. Exceptionally high levels of permanent job loss during the recent recession and its aftermath, associated at least in part with job restructuring by many prominent firms, are one candidate for explaining the unusual weakness in consumption over this whole period. ${ }^{10}$ Recessions typically cause a rise in both temporary layoffs and permanent job terminations. The contribution of each to the aggregate unemployment rate is not parallel because the average duration of spells from temporary layoffs is shorter. But past recessions reveal a characteristic pattern of unemployment from these two sources, as seen in figure 4, which plots the ratio of unemployed workers on layoff to those with permanent job loss. The ratio was about normal during the expansion of the 1980s. But in the 1990-91 recession, the ratio never approached the peaks of previous recessions. And it has sunk to new lows during the recovery. Equation 1, predicting the change in the log of permanent job losers, $U P$, from current and lagged values of the change in the log of those laid off temporarily, UT, underpredicts permanent job loss by 30 percent by the end of 1992 .

10. James Medoff (1992) first called attention to permanent job loss in recent years in "The New Unemployment." 


$$
\Delta \ln U P=0.003+0.07 \Delta \ln U P(-1)+0.77 \Delta \ln U T(L)
$$

$\overline{\mathrm{R}}^{2}=0.75 ;$ Durbin-Watson $=1.97$; period: 1968:2-1989:4; ( $t$-statistics in parentheses).

Data on permanent job loss are available only from 1967, so they cannot be used in equations like those in table 5 . But in equation 2 , which has the same form as equation 5-1 but is fit to 1967:3-1989:4, the rate of permanent job loss explains consumption better than does the aggregate unemployment rate, $U$.

$$
\begin{aligned}
& \Delta \ln C O N S=0.007+0.20 \Delta \ln D P I(L)-0.40 \Delta F E D F(L) \\
& (-5.41) \\
& +0.001 \Delta U(-1)-1.34 \Delta U P(-1)-0.001 D 80 \\
& \text { (0.22) (-1.51) (-1.26) }
\end{aligned}
$$

$\overline{\mathrm{R}}^{2}=0.25$; Durbin-Watson $=2.10$; period: 1967:3-1989:4; ( $t$-statistics in parentheses).

The importance of permanent, as opposed to temporary, job loss in affecting consumer attitudes and spending is easy to understand. If there is a distinctive role of expectations of job loss during recessions that affects consumption over and above the effect of actual income loss, permanent job losses should have a disproportionate influence on those expectations. Furthermore, the failure of the economy to produce new jobs would be especially damaging alongside the high rate of permanent losses.

\section{Financial Institutions and Financial Structure}

The exceptional underprediction of activity in some sectors during the recent downturn and recovery may also be related to special problems in the nation's credit markets that have been cited by many economists, financial analysts, and economic policymakers. Three main aspects of the credit markets have been identified as suspects. First is a capital shortage in the nation's banks, which shrank the supply of business loans. Second is a deterioration in the balance sheets of business firms following the debt explosion of the 1980s; this subsequently increased the price and nonprice cost of credit to would-be borrowers and made them more reluctant to borrow even at the same cost. Third is the 
excessively loose extension of credit for office buildings, commercial real estate, and related activities in the 1980s. This led to an overbuilding of commercial structures and left a legacy of collapsed real estate values and loan write-offs, which in turn contributed to write-downs in the value of bank (and other lenders') capital that helped bring on capital shortage problem mentioned above.

An extensive popular and academic literature has arisen about these problems. We cannot break major new ground in this paper, but will try to summarize results to date and discuss a few empirical findings that shed a little additional light on the subject.

\section{A Methodological Problem}

Comparing credit flows from various sources to various users across business cycles must be one component of any analysis of the role of financial flows in the recent recession. In comparing data on credit flows in different business cycles, the question immediately arises of how to handle the widely differing rates of inflation from cycle to cycle. In a period of rapidly rising prices, firms need substantial additions of nominal working capital merely to maintain a steady level of activity. At first, it would seem reasonable to measure the change in the real value of credit outstanding by taking the difference between the deflated values of outstanding credit at the beginning and the end of the period. But as Ben S. Bernanke and Cara S. Lown point out, the effect of inflation on business credit demands and flows is quite complex. ${ }^{11}$ The effect depends upon the relationship between the level of debt outstanding and the nature of the activity being financed. For example, because inventories turn over very quickly, a $\$ 1,000$ line of credit to finance them will have to be doubled if the price level doubles, even if no new activity is being financed. But if the value of outstanding debt is very high relative to the volume of activity to be financed in a given period, this will not be true. Thus, if the annual volume of gross fixed investment is, say, 5 or 6 percent of the stock-which itself had been financed by an accumulation of credits in the past-a doubling of the price level will require, in the short run, only a very modest addition to the nominal stock of outstanding debt in order to finance the existing real level of fixed investment outlays.

11. Bernanke and Lown (1991). 
At one end of the spectrum, the case of inventories, comparing credit flows across periods with different inflation rates should be done by measuring flows as the change in deflated levels of outstanding credit. At the other end, where outstanding debt is very large relative to the flows of activity being financed, the use of nominal flows is approximately correct even when comparing periods with widely different inflation rates.

As an approximation for an analysis of credit flows to business firms, we have grouped credit flows into two broad categories. The first are predominantly short-term flows, consisting of business loans by banks and nonbank sources plus commercial paper. For these, we calculated the period-to-period change in the deflated value of credit outstanding and then multiplied the implied real flow by the price level of the period. ${ }^{12}$ In the second group we placed predominantly long-term flows, consisting of mortgages and corporate equity issues and bonds. For these, we simply used the annual nominal flows, which in turn are the change in the nominal value of outstanding credit. Rather than express the results as percentage changes in the underlying outstandings, as is typically done, we used nominal GDP as a denominator metric, in order to compare the relative magnitude of changes both across time and among different types of credit flows.

In the case of short-term flows, this technique almost surely understates the difference between the credit flows in the recent recession and those in the 1969-70, 1973-75, and 1981-82 recessions, with their higher inflation rates. But relying on simple differences in nominal outstandings would have severely overstated the slowdown in credit during this recession compared to the last three. The opposite bias is true for the longterm credit flows. We think we have chosen the lesser of two evils. Nevertheless, because the deflated version of short-term credit flows is

12. The calculation of the "deflated" flows was, in fact, more complicated than explained above. The flow of funds time series on outstanding credits is characterized by a number of discontinuities, reflecting revisions, alterations in coverage, and other statistical changes. For some series in some periods, therefore, flows are not accurately measured by the change in the level of credit outstanding. Therefore we used a procedure whereby the outstanding value of a credit market liability at end-of-quarter $t-1$ was calculated by subtracting the published flow in quarter $t$ from the outstanding value at end-of-quarter $t$. This yielded a beginning and ending value of outstanding credit for each quarter. Each of these pairs of values were then deflated by the two-quarter averages of the surrounding GDP deflators and their difference (the deflated flow) was then reinflated with the quarterly GDP deflator to yield the appropriate series of flows. 
clearly imperfect, even if the lesser of two evils, we also provide estimates of purely nominal flows, and will refer to both these measures in the discussion. We treat the demand and supply of credit to the nonfinancial business, first excluding commercial real estate mortgages and then turning to that sector.

\section{The Role of the "Banking Crunch"}

That bank credit flows contract during recessions is hardly a unique phenomenon. Two necessary conditions must be fulfilled before one can assign an exogenous role in causing and/or prolonging the recession to developments within the banking system itself. First, the credit contraction must not be merely a passive response to a slackening demand for credit brought on by unfavorable macroeconomic developments or the banking sector's response to a tightening of monetary policy. Rather, the contraction must arise from developments within the banking system itself which reduce the supply of bank loans. Second, other financial intermediaries and channels between savers and investors must be unable to take up the slack, or do so at more expensive terms and conditions of credit supply.

THE BANK CAPITAL SHORTAGE. With respect to the first condition, the specific culprit often identified as the villain in the recent recession was a widespread shortage of bank capital brought on by some combination of three factors. First was the increased risk-based capital requirements stemming from the 1988 Basle agreements and a further stiffening of overall (unweighted) capital requirements by U.S. regulatory agencies; these were further strengthened by the practice of increasing minimum capital requirements for financially troubled banks. The second factor was the massive write-downs of those bank asset values predominantly associated with the collapse of the real estate boom of the 1980s. Third was a toughened set of loan evaluation standards used by bank regulators, determined not to be tarred with the brush of another S\&L fiasco. By forcing a lower valuation of some bank loans, these new standards reduced banks' measured capital.

Those banks with impaired capital-asset ratios-most of them troubled by a large volume of problem loans-found it difficult to float new equity as a means of raising capital to meet the required standards. Depending on the specific nature of the capital shortage, banks can take 
one of two steps to come into compliance with regulatory standards; both involve a supply-side contraction of loan volume. If they have enough capital to meet the overall (unweighted) capital requirements but not the risk-based measures, banks can shift their portfolios away from loans (which carry a high risk weight) to riskless short-term Treasury securities. If banks fall short of the overall requirements, they must shrink their deposit base. Presumably, they do so by reducing the rate they pay on managed liabilities.

The evidence is fairly strong that by the last years of the 1980s, capital shortages began to play a role in forcing many banks to reduce lending. Bernanke and Lown document that in New England, where bank capital shortages have been particularly severe, loan volume fell substantially further than in other regions in $1990 .{ }^{13}$ They find that in a regression of bank lending across states, a variable measuring the size of capital-asset ratios has a significant coefficient. A similar result emerges from their analysis of a cross-section of individual banks in New Jersey. Joe Peek and Eric S. Rosengren, in a cross-sectional analysis of New England banks, find that the rate of deposit growth was positively correlated to the level of capital-asset ratios, and argue that the homogeneity of conditions in the region weakens the role of differences in loan demand as a potential explanatory factor. ${ }^{14}$

However, the significance of these findings as an explanation for the recent economy-wide behavior of bank loans is not straightforward. As Bernanke and Lown point out, the coefficient of loan volume on capitalasset ratios (in their state cross-sections) implies that, in the recent downturn, only 2 to 3 percent of the 1988-90 decline in bank lending could be explained by changes in capital asset-ratios. ${ }^{15}$ However, we question the relevance of applying the cross-sectional coefficient on absolute changes in the capital-asset ratio to estimate the consequences of a tightening of regulatory standards. Among those banks that comfortably meet capital standards, differences in capital-asset ratios may explain little of the difference in loan volume. And among banks faced with capital shortages because of changing regulatory standards, a medium and a substantial shortage may initially elicit the same response. Nevertheless, the emergence of widespread capital shortages because of

13. Bernanke and Lown (1991).

14. Peek and Rosengren (1992).

15. Bernanke and Lown (1991, p. 228). 
soured loans or regulatory changes might still have an important impact, for a time, on aggregate loan volume.

On a conceptual level, it is important to remember that, except perhaps in New England, insufficient capital was never a problem afflicting more than a minority of banks-albeit in some regions, the minority was substantial. In a period of weakness in loan demand, it is quite possible that the unsatisfied customers of banks that were short on capital and contracting loans were, to some extent, accommodated by stronger banks, taking some or all of the macroeconomic sting out of the bank capital shortage, but still producing a significant correlation between loan activity and capital-asset ratios among individual banks. (For a qualification of this point, see the next section.) Nevertheless, taken altogether, the evidence seems quite strong that the supply of bank loans was indeed constricted in recent years by capital shortages. The ex post data on credit flows presented below are consistent with the findings reported above in this regard. But the literature so far has not succeeded in pinning down the magnitude of the phenomenon, either absolutely or in relationship to the simultaneous fall in the demand for loans that also occurred over the period.

ALTERNATIVE SOURCES OF CREDIT. When banks switch funds in their portfolios from loans to Treasury bills, the prior holders of T-bills find themselves with "excess" cash, which is likely to find its way back into the credit markets. And when banks discourage the inflow of deposits by lowering $\mathrm{CD}$ rates, the would-be depositors do not put the cash under a mattress, but make deposits elsewhere or purchase alternative assets, such as mutual fund shares or commercial paper. Economists have long recognized that flows of credit from different financial institutions and sources are not perfect substitutes for each other, and that monetary policy operated, in part, because of that ${ }^{16}$ This fact also motivates the new "credit view" of how monetary policy and the credit system work. ${ }^{17}$ Banks and other financial intermediaries have evolved to deal with the asymmetry of information between potential borrowers and suppliers of credit. Thus, customer-supplier networks and specialized knowledge about borrowers are built up by individual banks, and within regional banking systems. As a consequence, when a widespread

16. See, for example, Gurley and Shaw (1960) and Brainard and Tobin (1963).

17. This section draws on Bernanke's (1993) excellent exposition of the "new credit" view. 
capital shortage forces banks to curtail loans, the flow of credit works its way through other channels-only at a higher cost in terms of rates, terms, and conditions. And in some cases, the alternative costs may be infinite, in the sense that some borrowers cannot access the alternative sources at any cost. Many of the alternative channels feature securitized credit sold in national markets, to which many small and regional firms have no access; and, of course, the flotation of corporate stocks and bonds is not an alternative for unincorporated enterprises.

This new credit view is consistent with the existence of credit rationing as described by Joseph Stiglitz and Andrew Weiss, but does not depend upon it. ${ }^{18}$ All that is necessary is that the alternative channels are more costly. To the extent that this is the case, the result is equivalent to an upward shift in the LM curve in an IS-LM model (with the interest rate to borrowers on the vertical axis). For a given monetary policy, the spread widens between open market interest rates and the effective rates that potential borrowers have to pay. ${ }^{19}$

To the extent that alternative sources of credit are indeed significantly imperfect as substitutes for bank credit, establishing the existence of some substantial supply-side blockage in the flow of bank credit-for example, a capital shortage-automatically yields the presumption that aggregate demand will be affected, because the effective cost of capital will be raised. But this does not indicate the magnitude of the effect.

EMPIRICAL EVIDENCE: BORROWING COSTS. Because, according to the credit view, nonbank sources of credit are only imperfect substitutes, a supply-based contraction of bank credit arising from capital shortages should raise the effective cost of borrowing (including nonprice terms and conditions) to business firms relative to market interest rates. Unfortunately it is difficult to test this hypothesis because of changes in loan quality. One of the characteristics of a period of credittightening is the use of a more stringent quality screen by lenders. However, no quality-weighted index of the cost of borrowing exists. Thus the simple raw figures on the average cost of borrowing are likely to conceal

18. Stiglitz and Weiss (1981). See Bernanke (1993, p. 56).

19. Bernanke (1993) prefers to think of this as a downward shift in the IS curve (in a model in which the opportunity cost to money holders is on the vertical axis). For any given rate received by holders of near-money assets, the effective rate faced by borrowers rises and less investment is undertaken. For a formal treatment of the "credit" view, see Bernanke and Blinder (1988). 
offsetting movements; borrowing costs for loans of given quality may rise, but this is masked in the reported data by an increase in average loan quality.

The evidence that does exist is skimpy. The spread between the prime rate and the federal funds rate widened during the current recession, as it does in all recessions. But then, it continued to rise to nearrecord levels and remained very high into early $1993 .{ }^{20}$ The spread between personal loan rates and the six-month CD rate also widened during the recovery to reach new peaks in $1992 .{ }^{21}$ The prime rate, however, is a notoriously poor index of what is happening to risk-adjusted borrowing costs. In any event, the behavior of both these spreads may be a simple artifact of the sluggishness of the current recovery. The prime rate and personal loan rate are both sticky administered prices; the funds rate is highly volatile, and the sluggishness of the current recovery has kept it low, unlike the more usual experience this far along into earlier recoveries. A calculation of the spread between the funds rate (or the CD rate) and the Fed-published rate charged on short-term business loans showed no systematic movements that would illuminate the problem at hand.

Unfortunately, to assess the importance of the bank capital shortage, we cannot rely on the evidence that might be provided by information on the price of credit; thus we must turn to the much more difficult task of trying to draw conclusions from ex post quantity data.

EMPIRICAL EVIDENCE: QUANTITIES. Commercial and industrial (C\&I) bank loans fell sharply during this recession and early recovery, both absolutely and-more importantly-in contrast to earlier business cycles. Over the period beginning five quarters before the business cycle peak and ending six quarters after the peak, the outstanding value of C\&I loans rose 35 percent in the average of the four recessions prior to 1990 (excluding the recession of 1980); in the current recession they declined slightly over the entire period. A similar difference can be seen when loans are taken as a ratio to final sales of business. ${ }^{22}$ Measured by nominal flows, the contraction of bank loans in the recent recession was substantially worse than in the other postwar recessions. But, as we

20. See Cantor and Wenninger (1993, p. 10, chart 3).

21. Cantor and Wenninger (1993, p. 11, chart 4).

22. Cantor and Wenninger (1993, pp. 25-26, charts 29 and 30). A similar sharp contrast shows up in data of table 1 in Bernanke and Lown (1991, p. 208). 
Table 8. Deflated Short-term Business Credit Flows by Type of Lender and Borrower Percent of GDP

\begin{tabular}{|c|c|c|c|c|c|c|c|c|}
\hline \multirow{2}{*}{$\begin{array}{l}\text { Lender and } \\
\text { cycle phase }\end{array}$} & \multicolumn{4}{|c|}{ Corporate borrowers } & \multicolumn{4}{|c|}{ Noncorporate borrowers } \\
\hline & 1969 & 1973 & $1981^{\mathrm{a}}$ & 1990 & 1969 & 1973 & $1981^{\mathrm{a}}$ & 1990 \\
\hline \multicolumn{9}{|l|}{ Banks } \\
\hline$P-9$ to $P-5$ & 0.35 & 0.36 & 0.13 & 0.30 & 0.03 & 0.02 & 0.10 & -0.04 \\
\hline $\mathrm{P}-4$ to $\mathrm{P}$ & 0.99 & 1.20 & 0.61 & -0.21 & 0.18 & 0.21 & 0.01 & -0.03 \\
\hline $\mathrm{T}-2$ to $\mathrm{T}+2$ & -0.27 & -1.19 & 0.74 & -0.60 & -0.03 & 0.05 & -0.33 & -0.21 \\
\hline $\mathrm{T}+3$ to $\mathrm{T}+7$ & 0.36 & -0.64 & 0.85 & -0.49 & 0.02 & 0.01 & 0.20 & -0.17 \\
\hline \multicolumn{9}{|l|}{ Nonbanks } \\
\hline$P-9$ to $P-5$ & 0.18 & 0.10 & 0.65 & 0.76 & 0.06 & 0.05 & 0.06 & 0.17 \\
\hline $\mathrm{P}-4$ to $\mathrm{P}$ & 0.27 & 0.19 & 0.22 & 0.53 & 0.20 & 0.17 & 0.12 & 0.01 \\
\hline $\mathrm{T}-2$ to $\mathrm{T}+2$ & 0.07 & 0.16 & -0.31 & -0.62 & 0.03 & 0.09 & 0.05 & -0.08 \\
\hline $\mathrm{T}+3$ to $\mathrm{T}+7$ & 0.10 & 0.22 & 1.06 & -0.15 & 0.05 & 0.24 & 0.33 & -0.12 \\
\hline
\end{tabular}

Source: Authors' calculations based on Board of Governors of the Federal Reserve System, Flow of Funds Accounts (nonfarm, nonfinancial business).

a. In contrast to previous tables, the 1980 recession is ignored, and 1981:3 is used as the peak of this recession.

noted above, for loans with relatively short maturities, there is a good case for using the difference in the deflated value of outstandings when comparing periods with widely different inflation experience.

Tables 8, 9, and 10 present comparative data on credit flows to nonfarm, nonfinancial business from bank and nonbank sources for the current and the three prior recessions, constructed as described earlier. For each business cycle, average flows during four periods are given: the two five-quarter periods ending at the business cycle peak, the five quarters centered around the cycle trough, and the succeeding five quarters, ending seven quarters after the trough. Table 8 summarizes short-term flows: bank loans, loans from other sources, and commercial paper. This table is based on the change in deflated outstandings (with the resulting flows reinflated to current prices). The data are cross-classified as to bank and nonbank sources (including commercial paper) and by corporate and noncorporate borrowers, as a crude device to look at the difference between large and small firms. Table 9 provides the same data on nominal flows. Finally, table 10 combines corporate and noncorporate business firms and bank and nonbank sources of funds, and adds the flow of credit to business through mortgages (except for home mortgages) and corporate issues of stocks and bonds. The data on mortgages and stocks and bonds represent nominal flows, while the short-term loan 
Table 9. Nominal Short-term Business Credit Flows by Type of Lender and Borrower Percent of GDP

\begin{tabular}{|c|c|c|c|c|c|c|c|c|}
\hline \multirow{2}{*}{$\begin{array}{l}\text { Lender and } \\
\text { cycle phase }\end{array}$} & \multicolumn{4}{|c|}{ Corporate borrowers } & \multicolumn{4}{|c|}{ Noncorporate borrowers } \\
\hline & 1969 & 1973 & $1981^{\mathrm{a}}$ & 1990 & 1969 & 1973 & $1981^{\mathrm{a}}$ & 1990 \\
\hline \multicolumn{9}{|l|}{ Banks } \\
\hline$P-9$ to $P-5$ & 0.80 & 0.77 & 0.81 & 0.76 & 0.09 & 0.07 & 0.35 & 0.07 \\
\hline $\mathrm{P}-4$ to $\mathrm{P}$ & 1.45 & 1.88 & 1.34 & 0.22 & 0.23 & 0.33 & 0.26 & 0.07 \\
\hline $\mathrm{T}-2$ to $\mathrm{T}+2$ & 0.26 & -0.30 & 1.12 & -0.24 & 0.03 & 0.25 & -0.23 & -0.13 \\
\hline $\mathrm{T}+3$ to $\mathrm{T}+7$ & 0.77 & -0.17 & 1.26 & -0.30 & 0.07 & 0.14 & 0.29 & -0.13 \\
\hline \multicolumn{9}{|l|}{ Nonbanks } \\
\hline $\mathrm{P}-9$ to $\mathrm{P}-5$ & 0.27 & 0.20 & 0.96 & 1.05 & 0.15 & 0.13 & 0.30 & 0.34 \\
\hline $\mathrm{P}-4$ to $\mathrm{P}$ & 0.37 & 0.34 & 0.58 & 0.83 & 0.29 & 0.31 & 0.38 & 0.17 \\
\hline $\mathrm{T}-2$ to $\mathrm{T}+2$ & 0.19 & 0.40 & -0.13 & -0.35 & 0.13 & 0.27 & 0.17 & 0.06 \\
\hline $\mathrm{T}+3$ to $\mathrm{T}+7$ & 0.20 & 0.38 & 1.26 & -0.02 & 0.13 & 0.37 & 0.46 & -0.04 \\
\hline
\end{tabular}

Source: Authors' calculations based on Board of Governors of the Federal Reserve System, Flow of Funds Accounts (nonfarm, nonfinancial business).

a. In contrast to previous tables, the 1980 recession is ignored, and 1981:3 is used as the peak of this recession.

flows are aggregated from table 8, which is based on deflated data. For comparability among the various categories, all data are expressed as percentages of GDP.

The flow of bank loans to both corporate and noncorporate business fell in the period leading up to the 1990-91 recession in a way not generally matched in other recessions. Indeed, the net flow of bank credit to noncorporate firms turned negative as early as 1988, an experience not matched in the years preceding earlier downturns. Nonbank loans and commercial paper flows were reasonably well-maintained for corporate borrowers during the two years prior to the 1990 business cycle peak. Although nonbank credit flows to noncorporate borrowers fell sharply in the year before the peak, that decline came a year later than the drop in bank credit. As might be expected, noncorporate loans from other than banking sources made up less of the post-1988 shortfall in bank loans than was the case for corporations, but until the recession continued to be positive.

This pattern confirms the earlier conclusion, based on existing literature, that the fall in bank loans prior to the current recession-certainly in late 1988 and 1989 and probably in 1990-was significantly driven from the supply side by emerging capital problems. While we cannot measure it, the shifting of the flow of credit away from banking into non- 
Table 10. Total Quarterly Business Credit Flows and Major Components Percent of GDP

\begin{tabular}{lrrrr}
\hline Component & 1969 & 1973 & $1981^{\text {a }}$ & \multicolumn{1}{c}{1990} \\
\hline Total $^{\text {b }}$ & & & & \\
$\mathrm{P}-9$ to $\mathrm{P}-5$ & 2.44 & 2.74 & 1.74 & 0.27 \\
$\mathrm{P}-4$ to $\mathrm{P}$ & 3.17 & 3.12 & 1.80 & -0.22 \\
$\mathrm{~T}-2$ to $\mathrm{T}+2$ & 2.65 & 1.21 & 1.26 & -0.66 \\
$\mathrm{~T}+3$ to $\mathrm{T}+7$ & 2.74 & 1.78 & 2.03 & 0.69 \\
Corporate stocks and bonds & & & \\
$\mathrm{P}-9$ to $\mathrm{P}-5$ & 1.82 & 2.21 & 0.80 & -0.92 \\
$\mathrm{P}-4$ to $\mathrm{P}$ & 1.53 & 1.34 & 0.84 & -0.53 \\
$\mathrm{~T}-2$ to $\mathrm{T}+2$ & 2.85 & 2.10 & 1.10 & 0.85 \\
$\mathrm{~T}+3$ to $\mathrm{T}+7$ & 2.21 & 1.94 & -0.41 & 1.63 \\
Short-term corporate and noncorporate & & \\
$\mathrm{P}-9$ to $\mathrm{P}-5$ & 0.62 & 0.53 & 0.94 & 1.19 \\
$\mathrm{P}-4$ to $\mathrm{P}$ & 1.64 & 1.78 & 0.96 & 0.31 \\
$\mathrm{~T}-2$ to $\mathrm{T}+2$ & -0.20 & -0.89 & 0.16 & -1.51 \\
$\mathrm{~T}+3$ to $\mathrm{T}+7$ & 0.53 & -0.16 & 2.44 & -0.94 \\
& & & & \\
Mortgages $\mathrm{d}$ & & & & \\
$\mathrm{P}-9$ to $\mathrm{P}-5$ & 1.34 & 2.35 & 1.79 & 1.57 \\
$\mathrm{P}-4$ to $\mathrm{P}$ & 1.36 & 2.66 & 1.27 & 0.65 \\
$\mathrm{~T}-2$ to $\mathrm{T}+2$ & 1.82 & 1.26 & 1.35 & 0.08 \\
$\mathrm{~T}+3$ to $\mathrm{T}+7$ & 2.35 & 1.21 & 2.35 & -0.58 \\
\hline
\end{tabular}

Source: Authors' calculations based on Board of Governors of the Federal Reserve System, Flow of Funds Accounts (nonfarm, nonfinancial business).

a. In contrast to previous tables, the 1980 recession is ignored, and 1981:3 is used as the peak of this recession.

b. Excludes mortgages.

c. Short-term credit is from the deflated version, table 8 . Rounding differences may occur.

d. Excludes home mortgages.

banking channels almost surely raised the average effective borrowing cost for business. And, as expected, the universe of smaller firms in the noncorporate sector did worse than the larger firms of the corporate world.

During the next two years of recession and relatively slow recovery, short-term flows to both corporate and noncorporate borrowers turned sharply negative, as shown in tables 8 and 10. Measured in deflated terms, the decline in total short-term credit flows was much larger than in the three historical episodes in the recession year, and its behavior was also much worse in the recovery. A striking fact is the degree to which nonbank sources of credit shared in the decline. The conclusions in this paragraph are not altered if the comparison is made using nominal 
flows. ${ }^{23}$ For the smaller firms of the noncorporate sector, the flow of nonbank credit, which had usually remained positive in other recessions and recoveries, was negative in the latest recession and early recovery.

Some supply-side forces may have contributed to the constriction of loan supplies from nonbank sources. Some captive auto finance companies, which raise the bulk of their funds short term in public credit markets, had their ratings downgraded, and experienced a sharp rise in loan loss reserves. ${ }^{24}$ And the fraction of commercial mortgages in foreclosure among life insurance companies rose far above prior experience. ${ }^{25}$ But it is unlikely that these problems impinged heavily on the supply of nonmortgage credit to most business firms.

All in all, the fact that nonbank credits fell so sharply strongly suggests that once the current recession got well underway, the principal force behind the drop in credit flows came from something other than bank capital shortages and other barriers on the supply side. That conclusion is strengthened, for the corporate sector, by the fact that during the early recovery, as was the case in earlier cycles, corporations floated large amounts of new stock and bond issues (see table 10); some of the decline in the outstanding value of corporate bank and nonbank credit represented voluntary refinancing.

One important fact that emerges from the data in tables 8,9 , and 10 is that the aggregate flow of short-term credit to business during the recession and early recovery, from both bank and nonbank sources, was far below what it had been during similar stages of the three earlier cycles. And even when corporate flotations of stocks and bonds are added, total flows of credit were depressed relative to earlier recession-recovery periods (see the figures for "total" credit flows in table 10). Because the recession of 1990-91 was shallower than the average of its three predecessors, it is a reasonable conclusion that credit flows fell by more than can be explained by the behavior of aggregate demand. The depressed level of credit flows continued during the recovery. Short-term credit

23. In the 1990-91 episode, the first quarter of the recession period $(T-2$ to $T+2)$ overlaps with the last quarter of the peak period $(\mathrm{P}-4$ to $\mathrm{P})$. If the overlapping quarter is removed from the recession period average, the decline in deflated total short-term credit during the recession is even greater than shown in tables 8 through 10 , principally because of the larger fall in nonbank credit. Conversely, the issue of stocks and bonds is greater by a roughly equal amount.

24. Cantor and Wenninger (1993, p. 16, chart 14).

25. Cantor and Wenninger (1993, pp. 15-16, charts 13 and 15). 
Table 11. Short-term Credit Flows to Noncorporate Business

Percent of GDP, current versus three prior cycles ${ }^{\mathrm{a}}$

\begin{tabular}{lccccr}
\hline & \multicolumn{2}{c}{ Real version } & & \multicolumn{2}{c}{ Nominal version } \\
\cline { 2 - 3 } \cline { 5 - 6 } Cycle phase & Prior average & Current & & Prior average & Current \\
\hline $\mathrm{P}-9$ to $\mathrm{P}-5$ & 0.11 & 0.13 & & 0.36 & 0.41 \\
$\mathrm{P}-4$ to $\mathrm{P}$ & 0.30 & -0.02 & & 0.60 & 0.24 \\
$\mathrm{~T}-2$ to $\mathrm{T}+2$ & -0.05 & -0.29 & & 0.21 & -0.07 \\
$\mathrm{~T}+3$ to $\mathrm{T}+7$ & 0.28 & -0.29 & & 0.49 & -0.17 \\
\hline
\end{tabular}

Source: Authors' calculations based on Federal Reserve, Flow of Funds Accounts (nonfarm, nonfincial business). a. The three prior cycles are those used in tables 8-10.

flows were substantially negative; but they were also negative to a small extent in the relatively strong recovery after the 1973-75 recession. Without an explicit model of the complex relationships between aggregate demand and credit flows, it is impossible to assess the implications of the weak credit flows during the recent recovery. Their weakness may simply reflect the fact that the recovery itself was uniquely sluggish.

To the extent that the corporate-noncorporate breakdown provides information on firm size, the data suggest that smaller firms, like larger ones, experienced very low flows of credit in the recent recession and recovery, as seen in table 11. Unlike corporations, however, noncorporate firms were not able to issue stocks or bonds to help them refinance their short-term debt obligations or to tide them over periods of low cash flow. As we noted earlier, credit flows to noncorporate businesses from both bank and nonbank lenders slowed sharply.

On balance, we read the evidence as confirming a definite and unique role for bank capital shortages in slowing the economy during the period leading up to the onset of recession itself. During the next two years, however, the decline in nonbank credit flows relative to past experience was also very large, suggesting that once the recession got underway, factors other than bank capital shortages became the principal driving force. But the data also provide evidence that the credit decline was not solely an endogenous response to overall weakness in the economy. ${ }^{26}$

26. This is essentially the conclusion reached by Bernanke (1993, p. 65). The aggregate data, however, cannot tell the full story. A number of banks-even if a shrinking numberremained capital-constrained. For many smaller firms no reasonable substitutes for bank loans exist. Within an aggregate dominated by a depressed demand for loans, it is nevertheless quite likely that some potential expansions in activity were eliminated by the continued existence of capital constraints among some banks. 
Table 12. Change in Nonresidential Construction during Recession and Recovery

Percent of beginning-of-period GDP

\begin{tabular}{rcc}
\hline Peak & $\begin{array}{c}\text { Peak io } \\
\text { trough }\end{array}$ & T to $T+7$ \\
\hline $1960: 2$ & 0.3 & 0.2 \\
$1969: 4$ & -0.2 & 0.1 \\
$1973: 4$ & -0.4 & -0.2 \\
$1981: 3$ & -0.1 & 0.2 \\
$1990: 3$ & -0.3 & -0.6 \\
\hline
\end{tabular}

Source: Authors' calculations based on NIPA.

The magnitude of the slowdown in credit flows during the recession itself appears to have been larger than can reasonably be explained by movements in aggregate demand. Something else-beyond either bank capital shortages or weak aggregate demand-appears to have been at work to depress the volume of business credit. We were unable to determine whether the continued weakness of credit flows in the early recovery was simply an endogenous response to the sluggishness of the recovery itself or also the result of other forces.

\section{The Special Case of Nonresidential Real Estate}

Table 12, based on quarterly data in constant prices, summarizes the contribution of nonresidential construction to the change in GDP during the recent recession and the first seven quarters of recovery, compared to past cyclical experience. Because multifamily construction and mortgage lending fell very sharply during this recession and early recoveryand for the sake of completeness in the coverage of business credit-we have included this category in the total. But for ease in nomenclature, we refer to the total as nonhousing construction. The downward drag of lagging nonresidential construction has been particularly marked during the recovery. ${ }^{27}$

Both the demand and supply of loans for commercial real estate collapsed in the past two years. The history of extensive overbuilding and mounting vacancy rates in shopping centers, office buildings, and related structures in the 1980 s is well documented. The subsequent col-

27. The total also contains farm mortgages. 
lapse of the boom and the resulting huge markdowns of commercial real estate loans in bank and other institutional portfolios became an important contributing factor to the emergence of bank-capital shortages. To a lesser extent, but still significantly, the flow of mortgages on multifamily residential properties also fell sharply, and turned negative in 1991 and 1992. The final section of table 10 summarizes the recent behavior of mortgage loans (excluding home mortgages), and shows how far that behavior departs from historical experience. The demand for such credit has obviously fallen precipitously, and is likely to remain low for some time. But it is also possible that a major source of the widespread views and plentiful anecdotes about the stringency of bank credit is the recently acquired hostility of bank managers and bank regulators toward financing commercial or developmental real estate projects. While it is possible that a few scattered viable commercial projects are being held up by the attitudes of managers and regulators, the dramatic fall of commercial mortgage lending is essentially a demand phenomenon.

\section{Problems with Business Balance Sheets}

We noted above that during the last recession, business credit flows were lower than could be explained by either bank capital shortages or weakness in economy-wide aggregate demand. One widely held-but also disputed-hypothesis attributes important responsibility for the historically depressed volume of business credit flows to balance sheet problems of highly leveraged business firms, and argues that this development helped bring on the recession and has continued to retard the recovery. ${ }^{28}$

The ratio of the debt of nonfinancial business firms to their GDP, which had been trendless during the 1960s, 1970s and the first half of the 1980 s, rose sharply thereafter. The development, spread, and in some cases, abuse of junk bond financing during the 1980s, and the problem of burdensome interest obligations encountered by some firms earlier involved in leveraged buyouts, attracted much publicity. Similarly, the dramatic collapse of commercial real estate values caused major and

28. For a statement of the view, see Friedman $(1991,1992)$ and Bernanke (1993). For a skeptical evaluation of the potential contractionary role of rising corporate debt, see Summers (1988). 
highly visible financial difficulties for many excessively leveraged real estate developers. (About three-quarters of outstanding commercial real estate mortgages have been issued by households and noncorporate firms.) A very high amount of debt in business balance sheets can affect both the demand and the supply of credit. The existence of interest payment obligations that have become very high relative to cash flow inhibits firms' willingness to invest in risky projects. The same phenomenon can simultaneously downgrade the quality of the borrowing firm to potential lenders, and thereby raise the cost of capital or cause the firm to be screened out of consideration when credit is being rationed.

To assess the potential importance of these balance sheet developments, we start with some aggregate and average measures. It is not that the averages and aggregates are themselves so significant, but they can serve as an index as to what might be happening among the most interest-burdened 10 or 20 percent of corporations, whose unusual financial difficulties could arguably provide a drag on economic recovery. One important measure of the potential problem of excessive corporate debt is the extent of the rise in the burden of corporate interest payments on corporate revenues and cash flow. Figure 5 provides several alternative indexes. The first is the ratio of interest payments by nonfinancial corporations to their gross domestic product. That ratio has trended upward for decades, reaching local peaks in recessions. A very similar pattern, also seen in the lower panel of figure 5 , is evident in the ratio of interest payments to gross cash flow, defined as corporate profits plus depreciation and interest payments minus corporate profits taxes. But until the mid-1980s, the entire rise in the ratio of interest payments to GDP, or to cash flow, had been due to an upward secular drift in the effective interest rate on corporate debt. Furthermore, the ratio of debt itself to GDP, or to cash flow of nonfinancial corporations, was trendless. This is captured by the line in figure 5 that shows the ratio of interest payments to GDP calculated over the entire period at a constant average effective interest rate on corporate borrowings (at the average 1983-90 level). This ratio is, of course, an index of the ratio of corporate debt to GDP. ${ }^{29}$ Starting in the mid 1980s, that ratio began to rise sharply, reaching a peak in early 1991 .

29. The average effective corporate borrowing rate was calculated as the ratio of the NIPA estimate of net interest paid by nonfinancial corporations to the end-of-quarter credit market debt of such nonfinancial corporations. The flow of funds data on the debt of nonfinancial corporations excludes, while the NIPA data on net interest and GDP of such 
Figure 5. Ratio of Net Interest to GDP and to Cash Flow for Nonfinancial Corporations

Ratio
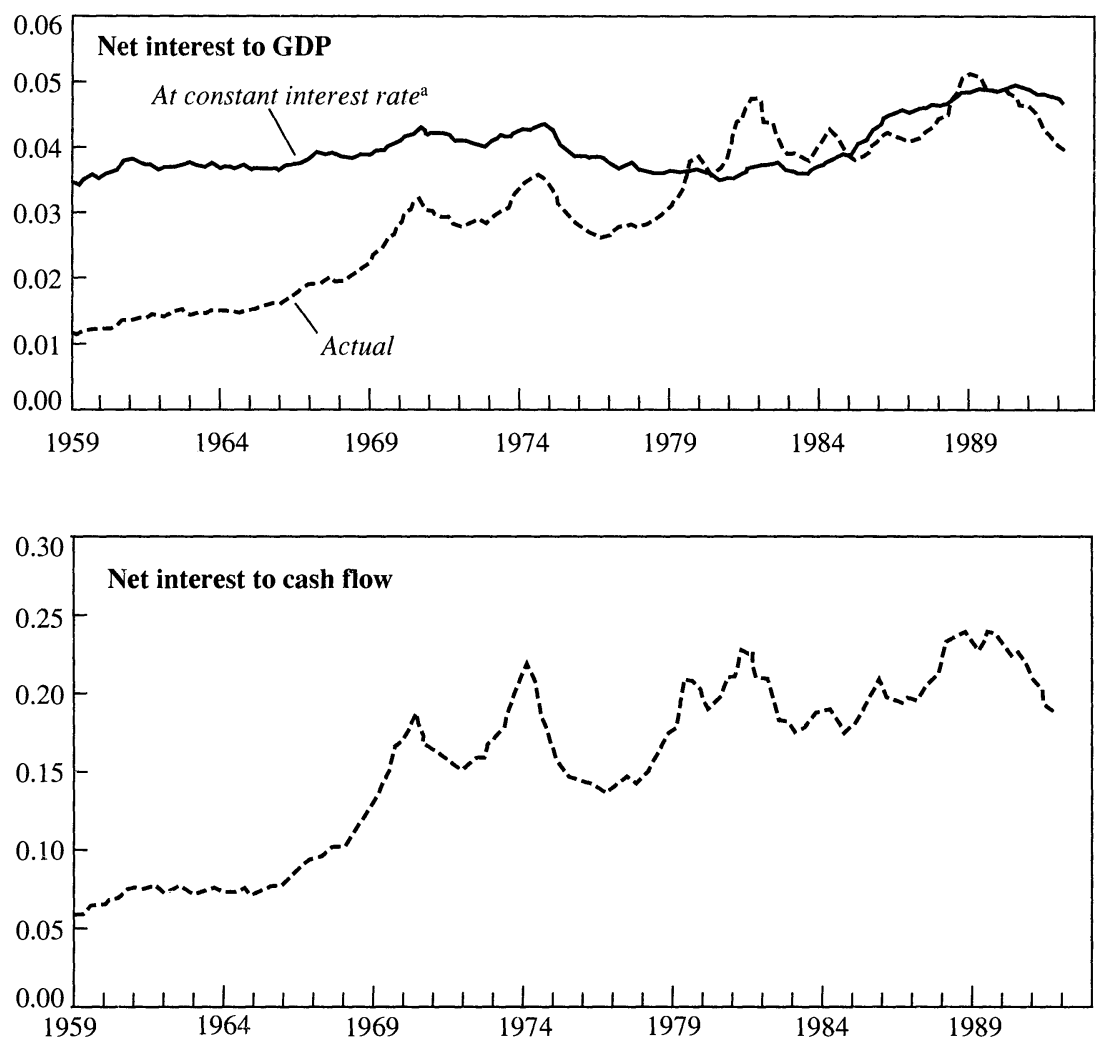

Source: Authors' calculations usirg nonfinancial corporate cash flow, net interest, and GDP from NIPA, and total nonfarm, nonfinancial corporate credit market instruments from the Federal Reserve, Flow of Funds data.

a The constant interest rate measure uses the average 1983-90 effective interest rate on corporate borrowing. See the text for further details.

In the last several years, the ratio of interest payments to GDP and to cash flow has fallen very substantially, bringing it back to where it was in the mid-1980s before the debt explosion began. But it is clear from figure 5 that the largest part of the decline in the interest burden has come

corporations includes, farm corporations. The error introduced by this difference, however, should be quite small. The interest-to-GDP ratio at constant interest rates shown in figure 5 represents a simple arithmetic calculation; it does not, of course, simulate what would have happened had interest rates over the entire period actually been constant at the level of 1983-90. In that case, many other economic developments, including possibly the debt-to-GDP ratio, would have been different. 
not from a declining debt ratio but from falling interest rates. ${ }^{30}$ The ratio of debt to GDP and the ratio of interest payments to cash flow at constant levels of interest rates have fallen, but modestly. Despite the recent improvement in the interest-to-cash-flow ratios, lenders and borrowers could well be concerned that the interest rates underlying those ratios are unrepresentative of future prospects. That would hardly be an unreasonable fear given the unusually steep yield curve that has characterized the last few years. And the fact that many corporations have recently begun to substitute substantial amounts of long-term bonds for short-term debt despite the highly unfavorable yield curve suggests that they were fearful of future increases in short-term rates. ${ }^{31}$ Short-term (ninety-day) commercial paper rates in the first quarter of 1993 were 3.2 percent; with the GDP deflator rising at a 3.3 percent rate, real rates were about zero. In 1988 and 1989, and also during the longer period of 1985 to 1990 , real commercial paper rates averaged in the neighborhood of 4 percent. In assessing risks (as opposed to making best forecasts), prudent lenders and potential borrowers would surely not rule out the possibility of a return partway back to those levels sometime during the next five years as an accompaniment to cyclical recovery in a world of low private saving rates and still substantial budget deficits. Thus the level of the debt-to-GDP ratio may be more relevant than the interestto-cash flow ratio in forming the attitudes of both borrowers and lenders about the risk of additional credit extensions.

While an upward movement in rates would not cause cash flow problems for most firms, it could be troublesome for those highly leveraged firms that have not yet succeeded in substantially reducing their debt. Such firms are, therefore, likely to continue to give high priority to using their cash flow and their access to financial markets to reduce and to extend the maturity of their debts, rather than to expand their operations.

30. Remolona and others (1993, p. 15) have estimated that nine-tenths of the reduced interest payments in 1991 and 1992 are attributable to lower short-term interest rates and that only 10 percent to corporate refinancing.

31. Remolona and his coauthors (1993, p. 15 , table 4 ) estimate that $\$ 87$ billion of corporate short-term debt was replaced by long-term debt in 1991-92 at an added annual interest cost of $\$ 3.5$ billion. Some of the motivation was undoubtedly to reduce the risk of having to roll over large short-term credits in the face of credit rationing and very unfavorable nonprice terms and conditions. But some of the willingness to accept higher immediate interest costs may have also reflected pessimistic views about future interest rate prospects. 
And to the extent that lenders evaluate credit risks with an eye to the possibility of future interest rate increases, their assessment of the creditworthiness of these firms will be more unfavorable than would be suggested by evaluating their prospects at today's interest rates.

So far we have considered only aggregate data. But the inhibiting effect on both borrowers and lenders of past increases in leverage will principally be concentrated among those firms with the highest leverage. In 1988, Bernanke and John Y. Campbell simulated a rerun of firm experiences in the 1973-75 and 1981-82 recessions on a sample of 1,200 firms, taking into account their actual 1986 debt-equity and coverage ratios. ${ }^{32}$ Together with Toni M. Whited, they later repeated the experiment with firms' 1988 balance sheet and income ratios.In the latter experiment, they found that a rerun of 1973-75 would threaten about 25 percent of the firms with insolvency, with simulated debt-asset ratios greater than unity. ${ }^{33}$ The better stock market performance of $1982 \mathrm{kept}$ the increases in simulated debt-asset ratios to a modest amount, but very substantial liquidity problems emerged for about 20 percent of the firms because of interest expenses in excess of cash flow. The authors also found that increases in debt-asset ratios over the 1980 s had not been particularly concentrated among cyclically stable firms. The depth of the 1991 recession was much less than the earlier two and the stock market behaved relatively favorably. But it is nevertheless quite possible that considerations similar to those raised by the simulations of Bernanke and his colleagues may have played a role on both the demand and supply side in producing the unusually large drop in business borrowing during the latest recession and early recovery, with an attendant inhibition on the volume of real investment activity.

In another recent study, Eli M. Remolona and others examined the factors behind the upsurge in corporate stock and bond financing that has occurred in the past several years. ${ }^{34}$ They concluded that the bulk of the new issues were devoted not to business expansion but to making up for subpar cash flows (depleted by heavy interest payments) and to deleveraging. Of the fifty largest new equity issues by seasoned firms during the eighteen months prior to July 1992, 44 percent (by value) were issued by firms losing money at the time of issuance and another 36 per-

32. Bernanke and Campbell (1988).

33. Bernanke, Campbell, and Whited (1990, p. 269).

34. Remolona and others (1992). 
cent by firms with a ratio of debt to book equity of more than 70 percent. ${ }^{35}$ The study's authors argue that "U.S. corporations found managing their debt in a period of weak cash flow more difficult than anticipated." ${ }^{36}$ During the 1980s, the argument had been advanced that precisely because creditors in a very leveraged firm would be exposed to severe and early losses in case of cash flow difficulties, they would have great incentive to agree on early intervention and a reduction in their claims before bankruptcy occurred. But as Remolona and his colleagues point out, that outcome was made more difficult "by the proliferation of creditor classes during the leveraging boom of the 1980 s. ${ }^{37}$ It turned out to be hard to get the different classes to agree on a refinancing proposal. Thus during 1991 and 1992, an important fraction of U.S. corporations had to use their access to the long-term credit markets to cope with the residue of the 1980 s leveraging boom, rather than to finance expansion.

In summary, financial developments almost surely did contribute to the macroeconomic problems of the past three years. The shortage of bank capital had some responsibility for the slowdown in economic activity that began in 1989. As the slowdown turned into a recession, the evidence-particularly the fact that nonbank credit flows also fell sharply-suggests that factors other than bank capital shortages took over as the driving force in the credit slowdown. Those other factors included not only the developing weakness in the aggregate demand for goods and services, but also the effects of the sharp rise in business debt burdens during the 1980s. The enlarged debt burdens reduced the creditworthiness of many business borrowers in the eyes of potential lenders and raised the potential bankruptcy risk of borrowing for many potential borrowers, thereby reducing their willingness to undertake real activities that required an increase in debt liabilities.

\section{Some Recent Improvements}

We concluded above that once the recession started, factors other than bank capital shortages played the dominant role in the contraction of credit flows, and that these in turn may have partly been the result of

35. Remolona and others (1992, p. 12, table 1).

36. Remolona and others (1992, p. 3).

37. Remolona and others (1992, p. 3). 
an earlier deterioration in business balance sheets. But in the absence of improvements, deficiencies in bank capital positions could reemerge as a constraint to financing the rapid credit expansion needed once the recovery became more vigorous. In fact, however, bank capitalization ratios and other indicators of health have been improving. By the end of 1992, the ratio of equity capital to assets among FDIC-insured commercial banks had risen to 7.52 percent from its low of 6.02 percent in $1987 .{ }^{38}$ The assets of FDIC-insured commercial banks classified as problem banks reached a peak in 1991 at 15.4 percent of total year-end bank assets; that ratio had dropped to 11.6 percent a year later. ${ }^{39}$

We have not been able provide a quantitative assessment of the extent to which bank capital ratios and business balance sheets remain an actual or potential constraint on the speed of economic recovery. The improvements to date have obviously relaxed the constraints, and those improvements are likely to continue. But to the extent that we have been correct in arguing that business balance sheets have been a restraining factor on business expansion-from the standpoint of both the supply and demand for credit - the improvement that has occurred to date does not appear to have been sufficient to have removed completely the constraints. To put this in perspective, however, recall from the earlier results that it was consumer spending, not business outlays on producers equipment and inventories, which was surprisingly weak in this recovery.

\section{Conclusion}

We have been able to tag the recent recession and subsequent sluggish recovery as clearly unusual in that-unlike its predecessors-it was not primarily driven by a combination of policy changes and autoregressive responses by other forces weakening total demand. We have pinpointed the weakness in consumption as the most important locus of negative shocks, and have suggested that it arose in part from the depressing effect on consumer confidence stemming from weak employment growth and from the unusual prevalence of permanent-as contrasted with temporary-layoffs. Additionally, we believe, lesser

38. FDIC (1992, p. 5).

39. FDIC $(1992$, p. 5$)$. 
shocks have arisen from early constraints on credit expansion arising from banks' capital shortages; the 1980s overbuilding and subsequent collapse in the market for commercial construction, as well as the effect on lenders' financial strength from the associated fall in the value of real estate loans; and some inhibitions on credit expansion following from the deterioration in business balance sheets during the 1980s.

More recently, bank profitability, capital ratios, and stock values have been improving, lessening whatever residue of problems still remains from the bank capital shortage. While the overall ratio of interest payments to GDP and to cash flow among nonfinancial corporations has improved substantially, the largest part of that improvement has resulted from falling interest rates, rather than from reductions in debt relative to GDP. Because of this, an important part of the improvement could be reversed with a future rise in interest rates, and anticipation of this could still be a constraint on some potential debt-financed activities among the most affected firms.

\section{APPENDIX}

\section{The Velocity of M2 around Recessions}

WE HAVE USED CHANGES in the federal funds rate as the most useful characterization of monetary policy. As noted in the text, the variability of the various monetary aggregates relative to other economic variables has kept the Federal Reserve from using such measures as their instrumental target during most of the postwar period. Table A-1 summarizes

Table A1. Percentage Change in M2 Velocity around Recessions

Percentage points

\begin{tabular}{|c|c|c|c|c|c|}
\hline \multirow[b]{2}{*}{ Recession } & \multirow[b]{2}{*}{$(P-4)$ to $P$} & \multirow[b]{2}{*}{$P$ to $T$} & \multirow[b]{2}{*}{$T$ to $(T+5)$} & \multirow[b]{2}{*}{ T to $(T+7)$} & \multirow{2}{*}{$\frac{\text { Annual rate }}{P \text { to } T}$} \\
\hline & & & & & \\
\hline 1960:2-1961:1 & 0.3 & -4.5 & 0.7 & -1.2 & -6.0 \\
\hline $1969: 4-1970: 4$ & 2.6 & -1.2 & -3.3 & -4.4 & -1.2 \\
\hline $1973: 4-1975: 1$ & 3.9 & 0.2 & -1.5 & -3.2 & 0.2 \\
\hline 1980:1-1982:4 & 2.1 & -5.7 & 0.3 & 0.8 & -2.1 \\
\hline 1990:3-1991:1 & 0.0 & -1.1 & 2.5 & 4.5 & -2.1 \\
\hline Mean, excluding 1990-91 & 2.2 & -2.8 & -1.0 & -2.0 & -2.3 \\
\hline Mean & 1.8 & -2.5 & -0.3 & -0.7 & -2.2 \\
\hline Standard deviation & 1.4 & 2.3 & 2.0 & 3.1 & 2.1 \\
\hline
\end{tabular}

Source: Authors' calculations based on NIPA and Federal Reserve Bulletin, various issues. 
the changes in $\mathrm{M} 2$ velocity during recession subperiods, in the same format as was used for other variables. The standard deviations of those changes across the various subperiods are typically more than half as large as the standard deviations of changes in GDP itself, as reported in text table 1 . 


\section{Comments and Discussion}

Benjamin M. Friedman: The subject of this stimulating paper by George Perry and Charles Schultze-broadly defined, the nature of economic fluctuations-is obviously an issue of very long standing. The paper's title is perhaps a self-conscious echo of the Tolstoian notion that while expanding economies are all alike, every contracting economy is contracting in its own way. The title notwithstanding, the paper's principal conclusion is that the U.S. economy's contraction in 1990-91 was pretty much like other contractions. What was unusual was the period leading up to that contraction and, even more so, the recovery that has followed.

In their analysis of the end of the 1983-90 expansion, the main puzzle framed by Perry and Schultze is why the recession took so long to begin. Their analysis focuses in particular on the false signal given by the federal funds rate, which they adopt as their primary indicator of monetary policy. The nominal federal funds rate began to rise sharply in early 1988, peaked in March of 1989, and had been steadily declining for a year and a quarter before the recession began. As Perry and Schultze point out, price inflation was sufficiently stable during this period that the real federal funds rate mostly tracked the nominal rate.

Although they do not say so, this is the same problem thrown up by substantially all familiar indicators of monetary policy during the episode that they examine. M2 growth, for example-taken as either nominal or real-declined sharply in early 1987, and it has remained low ever since. Bank loan growth moved more or less in step with M2 growth. The spread between the commercial paper rate and the Treasury bill rate, an indicator on which Kenneth Kuttner and I have focused in some recent work, rose as early as late 1987 to levels that almost always predict recessions, then declined, again rose to recession-indication levels 
in early 1989, but then declined to clearly nonrecession levels by late 1989 , long before the recession occurred. The spread between long- and short-term interest rates, an indicator that other researchers have emphasized, as have many market practitioners, likewise gave a false signal, predicting a recession long before one occurred and then switching to nonrecession levels just before the recession began. At least from a monetary and financial perspective, therefore, the period leading up to the 1990-91 recession was clearly unusual.

What has been even more extraordinary-and what now matters more importantly for current policy purposes-is the shape of the recovery. As Perry and Schultze document in some detail, real growth since the 1991 trough has been extraordinarily slow compared to prior U.S. recovery episodes. Moreover, because productivity has grown so rapidly, employment growth has been even slower. As the exchange between the Perry-Schultze paper and Robert Gordon's paper in this volume highlights, the extremely slow job growth during this recovery is an interesting phenomenon in its own right. Further, as recent evidence introduced by James Medoff has indicated, measures of job availability turn out to be good predictors of consumer confidence, as well as of voting behavior in elections. Perry and Schultze politely ignore the fact that a presidential election took place eighteen months into this sluggish recovery, and so they do not speculate about whether the election might have turned out differently had growth of real income-or, more importantly, unemployment-been more rapid during this period.

The main question is, why is this so? Why have real output and employment been so weak? Perry and Schultze's regressions clearly indicate that the weakness has not been due to causal factors readily identifiable with monetary or fiscal policy, at least not in the usual sense, and this finding confirms the conventional wisdom on this subject.

Because intellectual discourse abhors a vacuum, it is not surprising that many people have suggested other potential explanations for the sluggishness of the recovery. (Some of these potential explanations even have the competitive advantage of having been offered in advance of the event.) Among these, the one on which Perry and Schultze choose to focus-rightly, in my judgment-is the financial strain associated with the corporate-leverage movement of the 1980s.

There are two distinct sides of this argument. The first is that rising debt burdens have restrained nonfinancial firms' willingness and/or abil- 
ity to undertake expansionary activities that they otherwise would have pursued. Perry and Schultze have followed the recent literature in considering these debt burdens from the perspective of both stocks (that is, balance sheet relations) and flows (that is, interest-coverage ratios). The authors nicely document the extraordinary extent to which U.S. corporations leveraged themselves during the years spanning 1984 to 1989 . Although they do not say so explicitly, what is most relevant here is that the unprecedented volume of debt issued by nonfinancial corporations during this period was not the counterpart of financing a boom in investment. No investment surge took place during this period. More than half of the entire net volume of debt issues by U.S. nonfinancial corporations during this period simply went into one or another kind of transaction that, in effect, paid down the corporate sector's equity.

On the basis of this unprecedented development, several researchers (myself included) had earlier expressed concerns that if a big enough recession came along, defaults on this debt might become sufficiently widespread to threaten the integrity of the U.S. financial system in a broader sense. This did not happen, at least in part because in the end the recession was not all that severe. But many researchers (again, I include myself) had also argued that, even without any systemic discontinuity, these debt burdens would impair the economy's ability to mount a sustained recovery after the recession ended. My reading of the PerrySchultze paper is that it nicely provides evidence that the excessive corporate debt burdens inherited from the 1980s have indeed had just this effect.

A second aspect of how the financial events of the 1980s have depressed economic growth in the 1990s is the impaired capacity of lenders to provide credit. This too is a familiar subject. It is also a difficult subject because it is so hard to identify demand shocks from supply shocks in the credit markets.

Suppose, for example, that the only shock that has hit the economy is some negative shock to credit supply. Further suppose that, because of this negative shock to credit supply, there is a reduction in the pace of aggregate nonfinancial economic activity. For any or all of the standard reasons, this decline in nonfinancial activity is likely to lead, in turn, to a decline in the demand for credit. Both bankers and economists might even look at the results after the fact and conclude that much of what had happened was a decline in credit demand, even though the only genuine 
shock to have affected the economy in the first place was a shock to credit supply. Especially when we realize how noisy our measurements of the relevant prices are in this market-that is, how poor a measure of the cost of credit the posted interest rate usually is-it is easily conceivable that the econometrician, coming along after the fact, could look at the evidence and conclude that the extent of the disturbance to economic activity attributable to credit supply was not significantly different from zero and therefore attribute the entire episode to something else.

Despite these difficulties, there is a growing body of evidence supporting the conclusion that negative supply shocks in the credit market have played a meaningful role in accounting for the recent unprecedented decline in the pace of net credit extensions in the United States, among commercial banks in particular. Perry and Schultze reexamine the available evidence on this subject and likewise reach the same conclusion. I agree.

I differ with their interpretation of this evidence in two ways, however. First, they correctly note that net credit extensions slowed not only at commercial banks but at thrifts, life insurance companies, finance companies, and other major categories of lending institutions. They interpret this broader credit slowdown as reflecting a decline in the demand for credit. But among these other kinds of lenders, no less than at the banks, it is plausible to believe that the accumulation of large write-downs of loan values, and hence of firm capital, negatively affected credit supply in a way quite parallel to what happened at banks. Among life insurance companies, the leading example in this regard is the Equitable, the country's third largest life insurance company, which experienced loan losses so severe that it had to change from a mutual company to a stock company in order to receive a cash infusion by which the company was, in effect, sold to a French insurer. Among nonbank finance companies, the leading example is probably Westinghouse Credit, which experienced such large losses that the company has, for all practical purposes, exited from the lending business. In short, the pervasiveness of the credit slowdown across different categories of lenders is not necessarily evidence that this was a demand-driven phenomenon. It merely demonstrates how broadly U.S. financial institutions participated in the excessive credit extensions that preceded the slowdown, and therefore in the losses that that excess produced. 
The other way in which I differ from Perry and Schultze's interpretation is that I would draw just such a connection, which they do not, between the negative supply shock to credit markets during 1990-92 and the excessive leverage assumed by nonfinancial corporations during 1984-89. A fundamental but often overlooked truism of all credit markets is that every borrower's liability is some lender's asset, and vice versa. The relevant implication in the current context is that every default by a borrower represents a shrinkage in the capital of some lender. Moreover, when lenders are firms whose own securities trade in rationally speculative markets, every increase in the perceived likelihood of default by a borrower also leads to a decline in the capital of some lender as priced in the market.

In their analysis, Perry and Schultze associate negative credit supply shocks only with commercial banks, and even for banks they attribute these negative supply shocks to the excessive lending that went before only in the limited (albeit very important) context of real estate loans. While much detailed firm-level research would be necessary to prove the point, I suspect that defaults and increases in the probability of defaults on loans undertaken by ordinary nonfinancial companies, apart from real estate, also played a significant role in impairing the capital of banks and other lenders during this period.

In sum, the Perry-Schultze paper usefully reminds us that not only the antecedents of the 1990-91 recession, but especially the recovery that has followed it, have differed from prior U.S. experience. And they have added to the growing literature calling attention to the importance of credit market phenomena in accounting for the sluggish recovery in particular. The paper is a welcome contribution in both respects.

James Tobin: A good Brookings Panel paper asks the central policyrelated questions of the day, and tries to illuminate them and if possible answer them with the help of sound theoretical and empirical analysis, applied with common sense. The Perry-Schultze study of the macroeconomic scene certainly lives up to that tradition. This ambitious paper covers a vast territory, conveys a great deal of information, and reaches important and sometimes surprising conclusions. If it does not answer all the questions it asks and raises some new ones-well, that, too, is an earmark of a good Brookings Panel paper. 
Is the latest recession different? Yes, but the difference lies not so much in the three quarters technically dated as a recession by the National Bureau of Economic Research (NBER) as in the preceding eleven "recovery" quarters and the subsequent five or more "recovery" quarters. The closest parallel seems to be the 1969-71 recession, also a shallow and short interlude between slow-growth periods. The analysis is complicated by the method of dating. In the course of my comments, I will argue for a cyclical dating system that takes as par for the economy its potential real growth rate, rather than zero. By that scoring system, the U.S. economy fell into recession in 1989:2 and did not emerge until $1992: 3$, if then. In that light, many of the symptoms of weakness over the past four years do not seem so surprising.

What caused the growth recession that began in 1989:2? George Perry and Charles Schultze find that the Federal Reserve overdid its precautionary tightening in the year prior to the recession. They show that the Fed pushed the federal funds rate to very high levels compared with previous prerecession episodes. Figure 2 of the paper suggests that overtightening began in 1988. Yet it is hard to fault the Fed for leaning harder against the wind as the long recovery whittled the unemployment rate down toward 5 percent. The Fed is more vulnerable to criticism for failing to reduce the federal funds rate faster and more decisively once the economy starts to weaken. Indeed the unusual financial obstacles to credit flows, often cited by Chairman Alan Greenspan and other Federal Reserve officials, should have been reasons for deviating from the normal policy reaction function in the direction of ease. Perhaps the central bank, failing to arrest the slowdown by timely and decisive action, let the economy slip from the grasp of its ordinary remedial policies.

Among Reaganomics conservatives, it is axiomatic that the 1990 tax increase was the culprit. But by that time, the economy was already in a growth recession. Figure 2 of the paper shows fiscal policy tightening in $1986-87$, as gauged by the high-employment surplus ratio. But ever since a temporary dip in 1988 , it has been pretty stable. If supply-siders are looking for negative effects of the tax changes of 1986 and 1990 on potential GDP and productivity, rather than on aggregate demand, those are not apparent and presumably would take a long time to emerge.

Perry and Schultze find that aggregate demand has been weaker in recent years than can be explained by monetary and fiscal policy. The weakness, they say, is spread across almost all components of final 
sales, as shown in table 6 of the paper. It is even greater than they say, because almost all their component demand regressions have negative trends (that is, disguised as negative constants in first-difference regressions, perhaps unintentionally).

The recent persistent weakness of aggregate demand in this economy is a challenging puzzle. Ours is a low-saving society, and the government is a big dissaver. Real short-term interest rates have been falling since 1989 and are as low as in the 1960s, as seen in figure 2 of the paper. The stock market is at levels, relative to capital goods prices, comparable to the 1960s. Why can't this economy generate enough investment to restore full employment? Is Alvin Hansen to be vindicated at long last? Is high technology now capital-saving?

My further comments have four parts. First, I elaborate the case for GDP-gap dating of business cycle recessions and recoveries. Second, I express some doubts about the authors' models. Third, I offer some remarks on credit crunch issues. Fourth, I discuss the employment-productivity-GDP nexus.

\section{GDP-Gap Cycle Dating}

My first point is to urge the authors and other analysts of the business cycle to shift to growth-oriented dating and definition of business cycle phases, recoveries, and recessions. I urge that on the chief NBER-cycle umpire, Robert Hall, who sat beside me at the BPEA meeting.

Discussion table D1 and figure D1 focus on the six cycle periods in the Perry-Schultze paper and show two different allocations of the 149 quarters beginning in the last quarter of 1955 . The first part of table D1 gives the conventional NBER dating, which classifies 34 quarters as recession and 101 as recovery. (There are seven quarters at each end, occurring in incomplete recoveries that began before 1955:4 or had not ended as of 1992:4.) The reason that most of the time the economy is in an NBER-recovery is, of course, that the trend of real GNP is positive and the criterion of recovery is any two quarters of positive growth, however small.

The middle of table D1, in contrast, bases cyclical dating on the gap from potential GNP. I estimated potential GNP to grow at 3.5 percent per year through 1973, and at 2.5 percent thereafter. Its level is fixed near business cycle peaks so that gaps are negative in overheated, infla- 
Table D1. Alternative Allocations of Quarters to Business Cycle Phases, 1955:4-1992:2a

\begin{tabular}{|c|c|c|c|c|c|c|c|}
\hline \multirow[b]{2}{*}{ Specification } & \multicolumn{6}{|c|}{ Business Cycles } & \multirow{2}{*}{$\begin{array}{c}\text { Total } \\
\text { quarters }\end{array}$} \\
\hline & $I$ & II & III & $I V$ & $V$ & $V I$ & \\
\hline \multicolumn{8}{|l|}{ NBER timing } \\
\hline Recession begins & $1957: 3$ & 1960:2 & 1969:4 & 1973:4 & 1980:1 & 1990:3 & $\ldots$ \\
\hline Recession quarters & 4 & 4 & 5 & 6 & 12 & 3 & 34 \\
\hline Recovery quarters $^{b}$ & 7 & 34 & 11 & 19 & 30 & . . & 101 \\
\hline Quarters in previous recovery ${ }^{b}$ & 7 & $\ldots$ & . . & . & .. & $\ldots$ & 7 \\
\hline Duration of recovery in progress & . & & & & . & 7 & 7 \\
\hline \multicolumn{8}{|l|}{ GNP-gap timing } \\
\hline Recession begins & $1955: 4$ & 1959:2 & 1968:2 & 1973:1 & 1978:4 & 1989:1 & . . \\
\hline Recession quarters & 11 & 8 & 15 & 9 & 17 & 14 & 74 \\
\hline Recovery quarters & 3 & 28 & 4 & 14 & 24 & 2 & 75 \\
\hline \multicolumn{8}{|l|}{ Discrepancies } \\
\hline $\begin{array}{l}\text { NBER recovery versus } \\
\text { gap recession quarters }\end{array}$ & 7 & 4 & 10 & 3 & 5 & 11 & 40 \\
\hline Before NBER peak & 7 & 4 & 6 & 3 & 5 & 6 & 31 \\
\hline After NBER peak & 0 & 0 & 4 & 0 & 0 & 5 & 9 \\
\hline
\end{tabular}

Source: Author's calculations

a. There are 149 total quarters for the six business cycle phases.

b. Of these, Perry and Schultze calculate four as pre-recession.

tionary periods. It turns out that potential GNP corresponds to 3 percent unemployment in the early 1950 s, to 4 percent in the 1960 s, to 5 and then 6 percent in the $1970 \mathrm{~s}$, and to 5.5 percent today. The gap is plotted in figure D1, which also indicates NBER-recession periods by shaded areas, and marks GNP-gap or growth recessions by overlapping crosshatched areas. In those recessions, the gap is getting larger, while in growth recoveries, it is getting smaller. By this criterion, recoveries and recessions account for virtually equal numbers of quarters.

The bottom lines of the table show the allocation of the discrepancies. They are most severe for the sixth episode, the one that mainly concerns the authors and the rest of us. In it are eleven quarters that NBER calls recoveries and that a gap methodology would call recession. Six of those are before the NBER peak; five so far fall after it.

Semantic anomalies of the current business cycle arise from those discrepancies and distort analysis. Prior to the short 1990-91 NBER recession, the GNP gap and the unemployment rate had been rising for a year and a half. Subsequent to it, the so-called recovery has been too slow to cut gap and unemployment as rapidly as in previous upswings. The episode is called a "jobless recovery," which would be recognized 
Figure D1. Real GNP Gap, 1955:4-1992:4

Percent of potential GNP

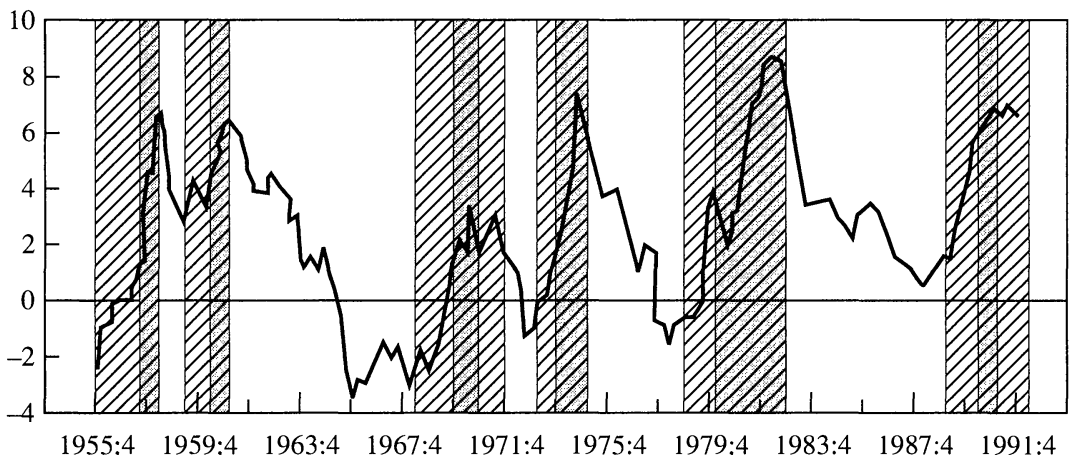

Source: Author's calculations.

a. The GNP gap is potential GNP minus actual GNP. Shaded intervals are NBER recessions. Cross-hatched intervals are GNP-gap recessions.

as an oxymoron if the alternative cyclical dating methodology were used.

It is especially unfortunate that the authors used the conventional NBER dating. All their variables are fractions of potential GDP, which has a positive trend. The core of their paper is a submodel of GDP determination "around recession" periods. It seems to me anomalous to choose the sample observations to which this model applies on the NBER dating methodology, which really presumes a zero growth trend.

\section{The Model}

The authors rely on a two-regime model of the determination of GDP. The regime of central interest applies to "around recession" quarters, which, in addition to the NBER recession itself, include the four quarters before the peak and the four after the trough. The other regime applies to the remaining observations.

What I miss is the logic of this split. Why should the economy be described by two different sets of equations, rather than just one? What is the mechanism that shifts the economy from one regime to the other? In the paper, those regime shifts are arbitrarily and exogenously determined ex post, by NBER recession-dating augmented by the authors' arbitrary four-quarter transition periods. Frequently, by the way, those periods are parts of a recession by growth-accounting criteria. 
A possible rationale for a two-regime model would be asymmetry in the effects of up and down movements of the independent variables. For example, recall Goodwin-Hicks flexible accelerator theory. The normal investment accelerator does not take hold when there is excess capacity. Idle plant and equipment must be worked off before the economy can return to the regime to which the accelerator mechanism applies. A similar example is the looseness of the relation of employment and production in cyclical contractions and early phases of recovery, discussed in connection with the Robert Gordon paper in this volume.

Quite a different reason for separating "around recession" periods would stem from the old neoclassical synthesis. The recession model would be Keynesian demand calculus, while the remaining observations would obey classical full employment equilibrium equations.

Perry and Schultze do not implement any of these ideas. They offer no theory for the split into two regimes. In practice, both specifications are pretty simple. GDP is determined by two policy variables: the federal funds rate for monetary policy and the high employment budget surplus for fiscal policy. The difference between regimes in this regression is simply that the coefficient for the fiscal policy variable during the recession periods is much higher. This is consistent with the hypothesis that the economy is more demand-constrained in the recession subsample.

\section{The Credit Crunch}

A common hypothesis about the current cycle is that debt burden and credit crunch explain the unusual sluggishness of the economy and its apparent unresponsiveness to expansionary monetary policy. Ben Friedman has covered this part of the paper at length, so I can be brief.

I think it is extremely difficult to conclude from observations of credit markets in what proportions observed declines in quantities, whether stocks or flows, are due to supply shifts and demand shifts. It is especially difficult in these markets, where rationing always occurs at observed interest rates and prices and where other contract terms are important but unobserved.

Consider, for example, evaluations of risk. If observers cannot correct for risk, they cannot tell whether the fact that a business firm is denied a loan means that lenders are more cautious or that this application 
would also have been denied five years ago. If the economy were more prosperous, presumably there would be less risk among potential borrowers than there is now perceived to be.

A new phenomenon in the banking system is capital deficiency, one important source of the so-called credit crunch. If banks are not meeting the capital ratio required and the market is unresponsive to equity issues, banks must curtail their holdings of assets to which the required ratio applies, and replace them with safe assets exempt from capital requirements or shed an equivalent amount of liabilities. The way to do the latter is to increase the differential between the rate charged on loans and the rate paid to depositors. Likewise, as banks shift to safe assets, the differential between the rates charged on loans and the rate available on Treasury securities and money market assets will increase.

Will the widening of these differentials mean higher rates on loans or lower rates on deposits and Treasury securities? That depends on competition in the open markets, external to the banks, in loans, deposits, and safe assets. Substitutability is evidently greater as between deposits and open market assets, including Treasury securities, than between bank loans to customers and open-market loans to big-name businesses. Consequently, if the Federal Reserve holds money market rates constant, then it is a rise in the bank loan rate that widens the differential.

Whether the problem stems from shocks to demand for or to supply of bank credit, a crunch of this kind can be remedied by a Federal Reserve policy that lowers the federal funds rate more than the Fed would normally do. Unfortunately, judging from Chairman Greenspan's frequent pronouncements, the Fed has instead used the credit crunch as an excuse for not easing policy more actively.

\section{Productivity and the GDP Gap}

Another puzzle on the current scene is whether the spurt in productivity in 1992 is transient or permanent. If more than a normal reversible cyclical phenomenon, it could be either a one-shot lift in potential GDP or a lasting increase in the rate of growth. The authors are properly agnostic but are inclined to agree with Robert Gordon that the productivity spurt is just cyclical. I do not know, but I can see some reasons to be more optimistic.

In normal business cycles, I think, employment becomes redundant 
in cyclical downturns because both overhead staff and production workers are kept on payrolls in excess of current needs. Employment falls, but mostly by attrition, and that takes time. The subsequent upturn of demand, sales, and production can be handled without hiring new workers, and measured productivity rises sharply. Later in recovery, further expansion requires hiring, and productivity growth reverts to its secular norm.

In the current business cycle, however, the downturn-especially in the growth-gap dating framework-was slow and gradual. There was plenty of time, even before 1992, for attrition to reduce employers' labor forces. Moreover, employers had plenty of incentive to dispense with workers, and inhibitions on layoffs are weaker than in previous cycles. As the paper notes, permanent job losers are a much larger fraction of the unemployed than in the past. The epidemic downsizings of large firms involve permanent layoffs, whose obvious purpose is to increase efficiency and cut costs.

If this is correct, what does it imply for the size of the current GDP gap? How much more GDP would be needed to get unemployment down to, say, 5.5 percent? Does the 1992 productivity news mean there is more slack in the economy than we thought (or would have thought had we known the statistical revisions that seem to indicate less slack).

At first glance, one would say there is more room for GDP expansion than is suggested by the CBO potential-GDP series used by the authors. But if the redundant labor of the recession has already been laid off, then rehiring will be needed sooner in the recovery. One of the components of the Okun's Law coefficient will be missing. On the other hand, some of those job losers may be swelling the ranks of those not in the labor force and may be ready to return when jobs become available again. The fact that the participation rate is abnormally low supports this possibility.

Jobs are desperately scarce. James Medoff points out that the best proxy we have for vacancies-the Conference Board Help Wanted Index, deflated by an employment index-is extraordinarily low relative to current unemployment rates. At 7 percent unemployment, jobs are as scarce as they were when unemployment rates were much higher, as in the recession troughs of 1975 and 1982. The Beveridge curve apparently has shifted down vertically.

As the authors note, job scarcity is a likely source of low consumer 
confidence and cautious consumption spending. It is also probably a brake on wage increases, as the Fed should note. In previous recessions, many observers, including Federal Reserve officials, have alleged that unemployment was not Keynesian and cyclical, but classical and structural. This diagnosis would be indicated if increased unemployment were accompanied by increased vacancies, as would happen if there were more mismatches between them. In unemployment-vacancies space, this would be an outward and upward shift in the Beveridge curve. That is definitely not what we have today.

\section{General Discussion}

Robert Hall defended the criteria used by the NBER dating committee to define recessions against James Tobin's suggestion that a GNPgap measure would be preferable. Hall argued that the measurement of potential GNP would become highly politicized, which would interfere with the function of the dating committee. He recalled the situation in 1980 , when a rapid bounceback occurred after an initial short recession, followed by a plunge into recession in 1981-82. The GNP-gap measure would have shown only one recession during this period, whereas the NBER method showed two. Use of the NBER criteria had therefore relieved political pressure to describe both recessions as a single Carter recession.

Several participants took up the issue of why the current recession was so long in coming. Martin Baily asked whether it was an overhang recession, characterized by large overcapacity in certain types of capital. Christopher Carroll suggested that the authors had rounded up a number of co-conspirators who had caused the recession, but had not pinpointed who had actually pulled the trigger. Richard Cooper proposed that there was no mystery about the trigger of the current recession: it was the result of soaring spot oil prices following the 1990 invasion of Kuwait, which he attributed to mismanagement of the strategic oil reserve. Consumers recalled the effects of the 1979-80 oil crisis; this shocked their expectations, lowering consumption. Robert Gordon agreed with the analysis that there was a hangover element to the current recession, together with an end-of-expansion effect in the labor market, and that the Kuwait shock had been decisive in the onset of the reces- 
sion. However, these did not explain the weakness in two large sectors-defense and construction.

In response, George Perry acknowledged the importance of the $\mathrm{Ku}-$ wait trigger in causing the recession. However, he pointed out that the flurry in oil prices was brief and that both before the invasion and after the Kuwait war was over, sustained overpredictions appeared in the regressions for GDP and most of its major demand components. Carroll proposed that there were really two issues: first, what brought on the recession and second, what caused the recovery to be so weak.

Baily noted the difficulty of identifying supply and demand factors in the credit market. The fall in the real estate market depressed the demand for loans, while simultaneously weakening the position of the banks, hence squeezing the supply of loans. Carroll was skeptical about a credit crunch explanation for the recent recession because it did not adequately account for the drop in consumption, an expenditure category less affected by credit, which was the most significant feature of the recession. However, Schultze suggested that credit supply constraints may have been important through a less direct route. If they affected small businesses and other firms that typically lead recovery through new hiring, the lack of this new employment may have restricted consumption. In this connection, Cooper suggested that banks may be an important source of funds for nonbank intermediaries. However, Benjamin Friedman reported that according to the flow of funds tables, banks provide only 5 percent of the funds of nonbank lenders. 


\section{References}

Bernanke, Ben S. 1993. "Credit in the Macroeconomy." Federal Reserve Bank of New York Quarterly Review 18(1):50-70.

$\longrightarrow \rightarrow-$, and Alan S. Blinder. 1988. "Credit, Money, and Aggregate Demand." American Economic Review, Papers and Proceedings 78(2):435-39.

- and John Y. Campbell. 1988. "Is There a Corporate Debt Crisis?" BPEA, 1:1988, 83-125.

- John Y. Campbell, and Toni M. Whited. 1990. "U.S. Corporate Leverage: Developments in 1987 and 1988." BPEA, 1:1990, 255-78.

- , and Cara S. Lown. 1991. "The Credit Crunch.” BPEA, 2:1991, 205-39.

Blanchard, Olivier Jean. 1992. "Animal Spirits, Consumption and the Recession of 1990-91." American Economic Review, Papers and Procedings 83(2):270 74.

Brainard, William C. 1967. "Uncertainty and the Effectiveness of Policy." American Economic Review, Papers and Proceedings 67(2):411-25.

_ and James Tobin. 1963. "Financial Intermediaries and the Effectiveness of Monetary Controls." American Economic Review, Papers and Proceedings 53(2):383-400.

Cantor, Richard, and John Wenninger. 1993. "Perspective on the Credit Slowdown." Federal Reserve Bank of New York, Quarterly Review 18(1):3-36.

Carroll, Christopher D. 1992. "The Buffer-Stock Theory of Saving: Some Macroeconomic Evidence." BPEA, 2:1992, 61-135.

Dunkelberg, William C., and William J. Dennis Jr. 1992. "The Small Business Credit Crunch." Unpublished paper. National Federation of Independent Business (December).

Federal Deposit Insurance Corporation. 1992. FDIC Quarterly Banking Profile (fourth quarter).

Friedman, Benjamin M. 1991. "Views on the Likelihood of the Financial Crisis." In The Risk of Economic Crisis, edited by Martin Feldstein. Chicago: University of Chicago Press.

- 1992. "Financial Roadblocks on the Route to Economic Prosperity." Challenge 35(2):25-34.

Gordon, Robert J. 1984. Macroeconomics. Boston: Little, Brown and Company.

1993. "The Jobless Recovery: Does It Signal a New Era of ProductivityLed Growth?" BPEA, 1:1993, 271-306.

Gurley, John G., and Edward S. Shaw. 1960. Money in a Theory of Finance. Washington: Brookings.

$\rightarrow$ Hall, Robert E. 1993. "Macro Theory and the Recession of 1990-91."American Economic Review, Papers and Proceedings 83(2):275-79.

Medoff, James L. 1992. "The New Unemployment." Unpublished paper prepared for Senator Lloyd Bentsen, Joint Economic Committee, U.S. Congress (April). 
Peek, Joe, and Eric S. Rosengren. 1992. "Crunching the Recovery: Bank Capital and the Role of Bank Credit." Paper prepared for Conference on Real Estate and the Credit Crunch, Federal Reserve Bank of Boston (September 16).

Remolona, Eli M., and others. 1992. "Corporate Refinancing in the 1990s," Federal Reserve Bank of New York Quarterly Review 17(4):1-27.

$\rightarrow$ Stiglitz, Joseph, and Andrew Weiss. 1981. "Credit Rationing in Markets with Imperfect Information." American Economic Review 71(3):393-410.

Summers, Lawrence. 1988. "Comment on Ben S. Bernanke and John Y. Campbell, 'Is There a Corporate Debt Crisis?' " BPEA, 1:1988, 130-36. 